\title{
Multitarget Biological Profiling of New Naphthoquinone and Anthraquinone-Based Derivatives for the Treatment of Alzheimer's Disease
}

\author{
Marta Campora, Claudio Canale, Elena Gatta, Bruno Tasso, Erik Laurini, Annalisa Relini, Sabrina Pricl, \\ Marco Catto, and Michele Tonelli*
}

Cite This: ACS Chem. Neurosci. 2021, 12, 447-461

Read Online

ACCESS | Lلll Metrics \& More | 国 Article Recommendations | s supporting Information

ABSTRACT: Two series of naphthoquinone and anthraquinone derivatives decorated with an aromatic/heteroaromatic chain have been synthesized and evaluated as potential promiscuous agents capable of targeting different factors playing a key role in Alzheimer's disease $(\mathrm{AD})$ pathogenesis. On the basis of the in vitro biological profiling, most of them exhibited a significant ability to inhibit amyloid aggregation, PHF6 tau sequence aggregation, acetylcholinesterase (AChE), and monoamine oxidase (MAO) B. In particular, naphthoquinone 2 resulted as one of the best performing multitarget-directed ligand (MTDL) experiencing a high potency profile in inhibiting $\beta$-amyloid $\left(\mathrm{A} \beta_{40}\right)$ aggregation $\left(\mathrm{IC}_{50}=3.2 \mu \mathrm{M}\right)$, PHF6 tau fragment $(91 \%$ at $10 \mu \mathrm{M})$, AChE enzyme $\left(\mathrm{IC}_{50}=9.2 \mu \mathrm{M}\right)$ jointly with a remarkable inhibitory activity against $\mathrm{MAO} B\left(\mathrm{IC}_{50}=7.7 \mathrm{nM}\right)$. Molecular modeling studies explained the structure-activity relationship (SAR) around the binding modes of representative compound $\mathbf{2}$ in complex with hMAO B and hAChE enzymes, revealing inhibitor/protein key contacts and the likely molecular rationale for enzyme selectivity. Compound 2 was also demonstrated to be a strong inhibitor of $\mathrm{A} \beta_{42}$ aggregation, with potency comparable to quercetin. Accordingly, atomic force microscopy (AFM) revealed that the most promising naphthoquinones $\mathbf{2}$ and $\mathbf{5}$ and anthraquinones $\mathbf{1 1}$ and $\mathbf{1 2}$ were able to impair $\mathrm{A} \beta_{42}$ fibrillation, deconstructing the morphologies of its fibrillar aggregates. Moreover, the same compounds exerted a moderate neuroprotective effect against $\mathrm{A} \beta_{42}$ toxicity in primary cultures of cerebellar granule cells. Therefore, our findings demonstrate that these molecules may represent valuable chemotypes toward the development of promising candidates for $\mathrm{AD}$ therapy.

KEYWORDS: Naphthoquinone and anthraquinone derivatives, multitarget-directed ligands (MTDLs), $A \beta$ and Tau aggregation inhibition, $A C h E$ and $B C h E$ inhibition, MAO inhibition

\section{INTRODUCTION}

Alzheimer's disease $(\mathrm{AD})$ is a progressive neurodegenerative disorder, mainly characterized by the loss of function and death of neurons in different areas of the brain. In spite of the high clinical and social impact owing to its global prevalence as the most common form of dementia, $\mathrm{AD}$ etiology still has to be clearly understood. Several factors concur to $\mathrm{AD}$ onset and progression, thus playing a pivotal role in the disease pathogenesis. The dysfunction of the basal acetylcholine (ACh) forebrain signaling, ${ }^{1}$ deposits of $\beta$-amyloid $(\mathrm{A} \beta)^{2}$ and tau-mediated neurofibrillary tangles (NFTs), ${ }^{3}$ and neuroinflammation are the major hallmarks of $\mathrm{AD}$. Soluble $\mathrm{A} \beta$ oligomers in concert with hyperphosphorylated tau serve as the main pathogenic contributors of neurodegeneration in $\mathrm{AD}$, acting in a synergistic fashion to cause cell death and neurotransmitter deficits. ${ }^{4,5}$ Also oxidative stress and free radical formation, ${ }^{6}$ metal dyshomeostasis, ${ }^{7}$ and neuroinflammatory processes ${ }^{8}$ are pathological components of the disease. The range of targets in $\mathrm{AD}$ is increasing, and for the most part, enzymes have been recognized as crucial contributors to $\mathrm{AD}$ onset and progression. ${ }^{9}$ Consequently, a number of molecules have entered clinical phase study with their targets, such as BACE1, phosphodiesterase, phospholipase A2, MAPK, and SIRT1, as examples (clinicaltrials.gov).

Bulk of evidence supports the $\mathrm{AD}$ multifactorial nature as a result of an intricate network of neurochemical factors that need to be simultaneously modulated to strive for a better disease outcome. In fact, the marketed anti-Alzheimer drugs, namely, the acetylcholinesterase (AChE) inhibitors and the NMDA receptor antagonist memantine, are regarded as merely symptomatic, since they work against a single target,

Received: September 27, 2020

Accepted: December 30, 2020

Published: January 11, 2021 

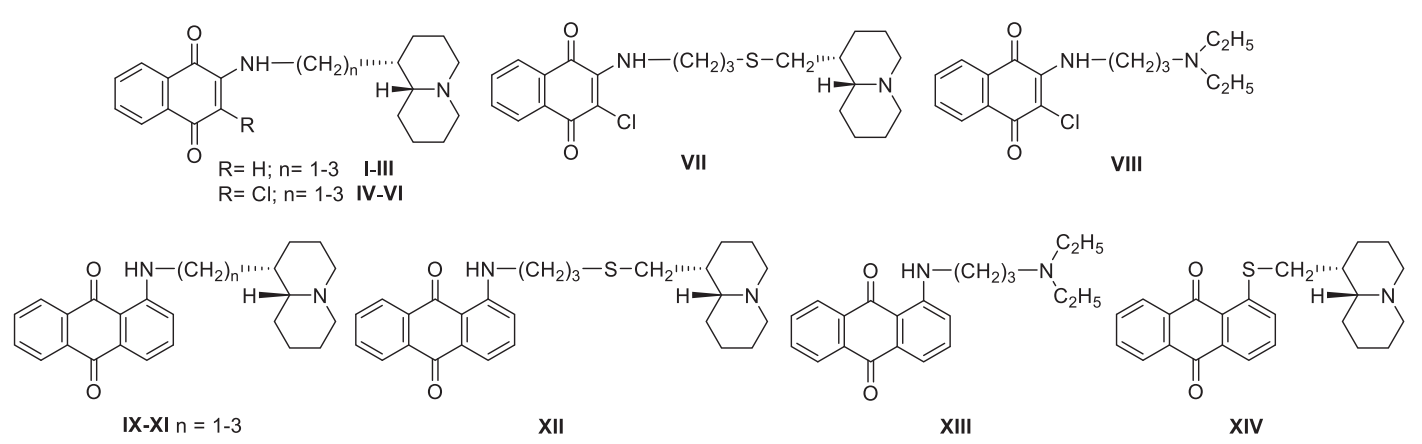

\begin{tabular}{ccc}
\hline Target & NQ range $\mathbf{I C}_{\mathbf{5 0}}(\boldsymbol{\mu M})$ & AQ range $\mathbf{I C}_{\mathbf{5 0}}(\boldsymbol{\mu M})$ \\
\hline $\mathrm{AChE}$ & $0.011(\mathbf{V I})-5.8(\mathbf{I})$ & $0.84(\mathbf{I X}, \mathbf{X})-3.8(\mathbf{X I V})$ \\
$\mathrm{BChE}$ & $4.1(\mathbf{V I I})-12(\mathbf{V I})$ & $1.1(\mathbf{X I I})-3.4(\mathbf{X I V})$ \\
$\mathrm{A} \beta_{40}$ & $61(\mathbf{V I I})$ & $6.4(\mathbf{I X})-61(\mathbf{X I I I})$
\end{tabular}

Figure 1. First series of the naphthoquinone and anthraquinone derivatives, bearing a dialkylaminoalkyl or a quinolizidinylalkyl chain, as multitarget agents inhibiting cholinesterases and $\beta$-amyloid aggregation: $\mathrm{NQ}=$ naphthoquinone; $\mathrm{AQ}=$ anthraquinone.<smiles>O=c1c(Cl)c(NCCc2ccccc2)c(=O)c1=O</smiles>

$n=3: 4$

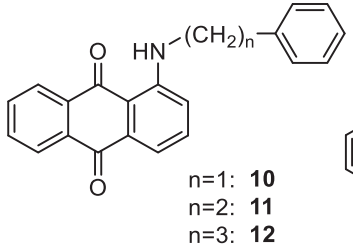

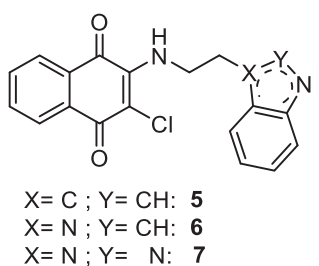
$\mathrm{X}=\mathrm{N} ; \mathrm{Y}=\mathrm{CH}: 6$
$\mathrm{X}=\mathrm{N} ; \mathrm{Y}=\mathrm{N}: 7$<smiles>[R7]CCc1ccccc1CCCOC(=O)C1=C(Cl)C(=O)c2ccccc2C1=O</smiles><smiles>O=C1c2ccccc2C(=O)c2c(NCCn3nnc4ccccc43)cccc21</smiles>

Figure 2. Structures of the investigated naphthoquinone and anthraquinone derivatives 1-14 as MTDLs for AD.

respectively modulating the cholinergic or glutamatergic function. ${ }^{10}$ This scenario has drawn greater attention on the multitarget-directed ligands (MTDL) strategy as these molecules may exhibit significant potential on the road to therapeutics for $\mathrm{AD} .{ }^{5,11-13}$

In this regard, the literature contains many examples of naphthoquinone and anthraquinone compounds from natural sources or synthetic as endowed with promising properties against diverse $\mathrm{AD}$ targets. Successfully, hybrid- and fragmentbased drug design strategies allowed the yield of multifunctional molecules, also based on naphthoquinone ${ }^{14-16}$ and anthraquinone $\mathrm{e}^{15,17,18}$ scaffolds which elicited antioxidant activity, $\mathrm{AChE}$ inhibition, $\mathrm{BACE}$ inhibition, inhibition of $\mathrm{A} \beta$, and tau aggregation.

Previously we investigated a library of thioxanthen-9-one, xanthen-9-one, naphthoquinone (I-VIII) and anthraquinone derivatives (IX-XIV) decorated with a basic side chain (especially quinolizidinylalkyl chains), which displayed a multitarget behavior by inhibiting both AChE and BChE, and the spontaneous aggregation of $\beta$-amyloid with similar potencies $^{16}$ (Figure 1). Naphthoquinones were dual AChEpreferring inhibitors $\left(\mathrm{IC}_{50}=0.011-5.8 \mu \mathrm{M}\right)$, while anthraqui- nones were equipotent toward both enzymes in the low micromolar range. On the contrary the tricyclic anthraquinone system was more suited to promoting the inhibition of $\mathrm{A} \beta$ aggregation (mean $\mathrm{IC}_{50} \sim 8 \mu \mathrm{M}$ ) than smaller naphthoquinones, which were generally endowed with less efficacy.

\section{RESULTS AND DISCUSSION}

2.1. Design. This report details our investigations to probe new additional substitutions on the naphthoquinone and anthraquinone scaffolds that have been tethered to an aromatic or heteroaromatic ring through a polymethylene chain, with a view to gaining a better understanding of their potential multitarget (promiscuity) profiles for AD (Figure 2). These novel hydrophobic features have been included with the aim of favoring suited hydrophobic interactions with a sequence of aromatic amino acids $\left(\mathrm{H}_{14} \mathrm{QKLVFF}_{20}\right)$ of $\mathrm{A} \beta$, which plays an important role in the initial phases of molecular recognition and structural transition and leads to $\mathrm{A} \beta$ aggregation in soluble oligomers and fibrillary species. ${ }^{14,19,20} \mathrm{AChE}$ continues to be a crucial target for $\mathrm{AD}$ therapy because of its noncholinergic functions as demonstrated by its chaperone role in $\beta$-amyloid 
toxicity, ${ }^{21}$ thus promoting the multitarget approach in order to hit at least $\mathrm{A} \beta$ aggregation and $\mathrm{AChE}$ activity. ${ }^{22}$ Besides AChE, $\mathrm{BChE}$ is another target of interest in the search for antiAlzheimer drugs, as this enzyme exhibits a compensatory effect in response to a greatly decreased AChE activity in the central nervous system (CNS) during AD progression. ${ }^{23}$ Additionally, excessive monoamine oxidase (MAO) activity contributes to neurodegeneration in $\mathrm{AD}$, inducing $\mathrm{A} \beta$ fibrillogenesis, ${ }^{24}$ imbalance of cholinergic, glutamatergic, and noradrenergic functions, ${ }^{25}$ and oxidative stress. ${ }^{26}$ Accordingly, the design of MAO inhibitors, or even better multipotent MAO and ChEs inhibitors, rapidly increased with a view to improving cognitive deficits and memory. ${ }^{27-29}$ Shikonin and acetylshikonin, characterized by the 5,8-dihydroxy-1,4-naphthoquinone scaffold (naphthazarin), were shown to be nonselective and reversible MAO inhibitors endowed with activity in the micromolar range. ${ }^{30,31}$ The unsaturated and lipophilic nature of their prenyl-like side chain resembled the hydrophobic features of substituents decorating the present quinone-based compounds (Figure 2), thus prompting us to also explore their potential as MAO inhibitors.

On the whole, in terms of targets selection, we move from amyloid and ChEs as relevant players in $\mathrm{AD}$ pathology to other targets with more credentials for a disease-modifying effect, such as tau and MAO B. ${ }^{32}$

Herein, the biological profiling included the in vitro evaluation of (i) self-induced $\mathrm{A} \beta$ and tau aggregation inhibition, (ii) the inhibitory activities against AChE and $\mathrm{BChE}$, and (iii) inhibition of MAO A and B isoforms. Atomic force microscopy (AFM) was then employed to assess the ability of the best performing $\mathrm{A} \beta_{40}$ inhibitors $(2,5, \mathbf{1 1}$, and 12) to impair $\mathrm{A} \beta_{42}$ fibrillation and revealed clear differences between $\mathrm{A} \beta_{42}$ aggregate morphologies obtained in the presence or absence of the compounds. The same compounds have been assayed for their protective effect against $\mathrm{A} \beta_{42}$ toxicity in primary cultures of cerebellar granule cells from postnatal rats (P7).

2.2. Chemistry. Compounds $1,3,^{33} 2,^{34} 5,9^{35}$ and $8^{36}$ have been achieved according to the cited references. For compound $\mathbf{1 0}^{37}$ we applied a different synthetic route with respect to the literature; thus its experimental properties have been reported herein as follows. Naphthoquinones 4, 6, and 7 were obtained by reacting the 2,3-dichloro-1,4-naphthoquinone, previously suspended in ethanol or methanol, with 2 equiv of the proper amine (Schemes 1 and 2).

\section{Scheme $1^{a}$}

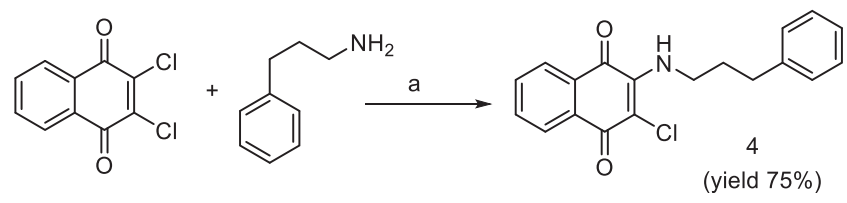

${ }^{a}$ Reagents and conditions: (a) EtOH, $\Delta, 4$ h.

The condensation at $160{ }^{\circ} \mathrm{C}$ of a mixture of 1 chloroanthraquinone with the proper aryl/heteroaryl alkylamine has given compounds 10-14 (Schemes 3 and 4).

The intermediate (heteroaryl)ethylamines required for the synthesis of the indoles 5 and 13, benzimidazole 6, and benzotriazoles 7 and $\mathbf{1 4}$ were prepared by reduction with $\mathrm{LiAlH}_{4}$ of 2-(3-indolyl)acetamide, 1-benzimidazolyl, and 1-
Scheme $2^{a}$

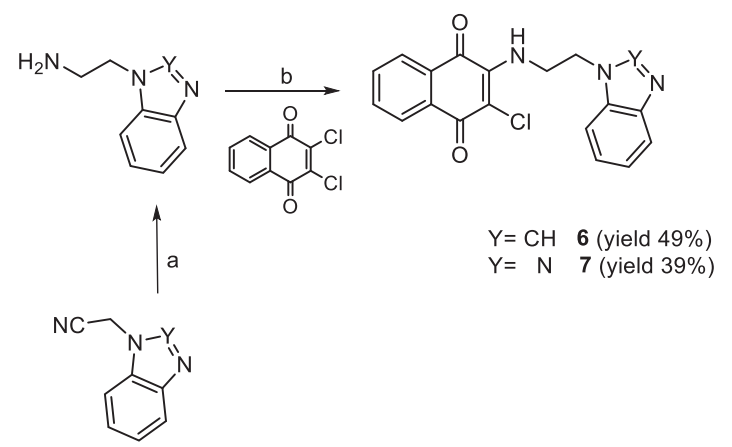

${ }^{a}$ Reagents and conditions: (a) $\mathrm{LiAlH}_{4}$ /anhydrous THF, $\Delta, 10 \mathrm{~h}$; (b) $\mathrm{MeOH}, \mathrm{rt}, 24 \mathrm{~h}$.

\section{Scheme $3^{a}$}

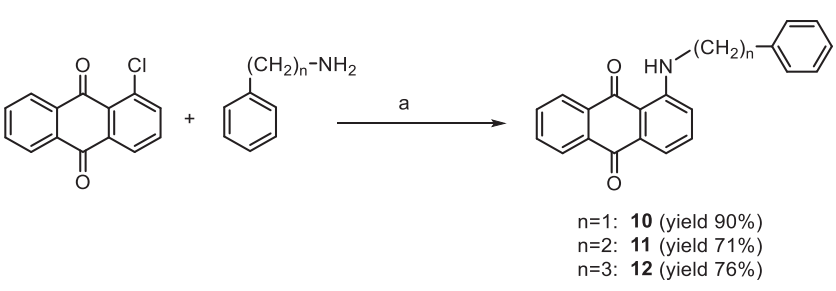

${ }^{a}$ Reagents and conditions: (a) $160{ }^{\circ} \mathrm{C}, 6 \mathrm{~h}$.

benzotriazolyl acetonitriles, respectively (Schemes 4 and 2). While 2-(3-indolyl)acetamide was commercially available, to synthesize 2-(benzimidazol-1-yl) and 2-(benzotriazol-1-yl) acetonitriles, benzimidazole and benzotriazole were condensed with 2-chloroacetonitrile in DMF in the presence of TEA according to the literature. ${ }^{38}$

The structures of the novel compounds have been confirmed using ${ }^{1} \mathrm{H}$ and ${ }^{13} \mathrm{C}$ NMR and elemental analysis. The purity of compounds (checked by elemental analysis) has been in all cases $>95 \%$.

2.3. In Silico and in Vitro Blood-Brain Barrier (BBB) Permeation. The use of naphthoquinone and anthraquinonebased derivatives as potential anti-AD agents requires their ability to enter the CNS. Accordingly, we tested in silico the propensity to cross the BBB by passive diffusion, calculating the LogPS values ${ }^{39}$ for the new compounds in comparison to the drugs donepezil, quercetin, safinamide, and the quinolizidine-containing naphthoquinone VI (Table 1, second column), whose BBB permeability profile was experimentally confirmed. $^{16}$

The results, listed in Table 1 , predicted that all the compounds are characterized by a brain-penetration ability comparable to the reference compounds and sufficient to obtain pharmacologically relevant concentrations within the CNS. As expected, the capability of amino acids naphthoquinones 8 and $\mathbf{9}$ to penetrate the BBB was poor, as LogPS values fell close to the lower limit of the recommended ranges $(-3<$ $\operatorname{LogPS}<-1)$, even if they could presumably reach the CNS by carrier-mediated active transport. The in vitro permeability $\left(P_{\mathrm{e}}\right)$ of compounds $2, \mathbf{5}, \mathbf{8}, \mathbf{1 1}$, and 12 was also determined using the PAMPA-BBB assays ${ }^{40}$ (Table 1, third column). Successful assay validation was performed by comparing the experimental permeability $\left(P_{\mathrm{e}, \exp }\right)$ with the corresponding reported values $\left(P_{\mathrm{e}, \text { rep }}\right)$ for 20 commercial drugs $\left(P_{\mathrm{e}, \exp }=\right.$ $0.9625 P_{\text {e,rep }}+0.2836, R^{2}=0.9622$, Figure $S 1$ and Table $\left.S 1\right)$. 
Scheme $4^{a}$

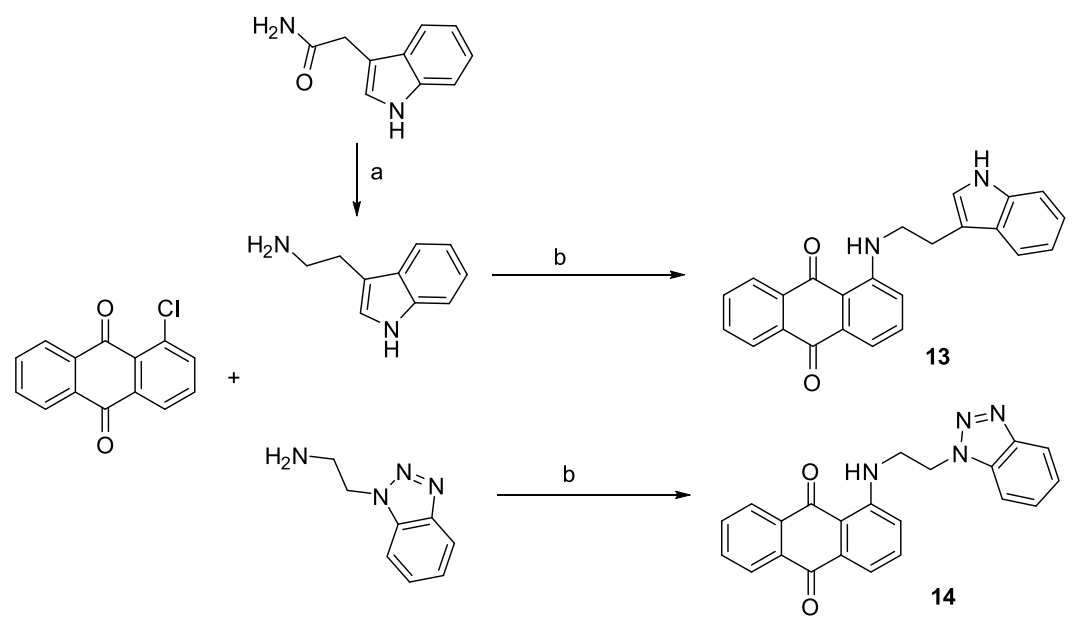

${ }^{a}$ Reagents and conditions: (a) $\mathrm{LiAlH}_{4} /$ anhydrous THF, $\Delta, 8 \mathrm{~h}$; (b) $160{ }^{\circ} \mathrm{C}, 6 \mathrm{~h}$.

Table 1. In Silico and in Vitro Evaluation of Naphthoquinone and Anthraquinone-Based Derivatives' Propensity to Cross $\mathrm{BBB}^{c}$

\begin{tabular}{|c|c|c|c|}
\hline Cpd. & $\operatorname{LogPS}^{a}$ & $P_{e}\left(10^{-6} \mathrm{~cm} / \mathrm{s}\right)$ & CNS prediction $^{b}$ \\
\hline 1 & -0.11 & & \\
\hline 2 & -1.1 & $28.4 \pm 2.1$ & CNS+ \\
\hline 3 & -1.1 & & \\
\hline 4 & -1.1 & & \\
\hline 5 & -1.2 & $14.3 \pm 1.3$ & CNS+ \\
\hline 6 & -1.3 & & \\
\hline 7 & -1.4 & & \\
\hline 8 & -2.5 & $6.1 \pm 0.4$ & CNS+ \\
\hline 9 & -2.8 & & \\
\hline 10 & -1.1 & & \\
\hline 11 & -1.1 & $24.7 \pm 2.2$ & CNS+ \\
\hline 12 & -1.1 & $22.0 \pm 1.9$ & $\mathrm{CNS}+$ \\
\hline 13 & -1.1 & & \\
\hline 14 & -1.2 & & \\
\hline Donepezil & -1.3 & $23.2 \pm 2.3$ & $\mathrm{CNS}+$ \\
\hline Quercetin & -3.6 & $0.14 \pm 0.06$ & CNS- \\
\hline Safinamide & -2.0 & & \\
\hline$\pi$ & -1.5 & & \\
\hline
\end{tabular}

${ }^{a}$ Rate of brain penetration, -3 (medium affinity) $<$ table $<-1$ (high affinity). PS represents permeability-surface area product and is derived from the kinetic equation of capillary transport. ${ }^{b} \mathrm{CNS}$ permeation prediction based on the PAMPA-BBB classification range from Di et al. ${ }^{4}{ }^{c}$ Measured as LogPS (ACD/Percepta Platform 2015 v14.0.0, https://www.acdlabs.com/). The last two columns report the experimental permeability results from the PAMPA-BBB assay $\left(P_{e}\right.$ $10^{-6} \mathrm{~cm} / \mathrm{s}$ ) and the corresponding predictive penetration in the CNS for compounds 2, 5, 8, 11, 12 and for donepezil and quercetin as positive (CNS+) and negative (CNS-) controls, respectively.

On the basis of the $P_{\mathrm{e}}$ values obtained, all analyzed compounds should be endowed with good-to-high $\mathrm{BBB}$ passive permeability, with $P_{\mathrm{e}}$ values ranging from 6.1 to $28.4 \times 10^{-6} \mathrm{~cm} / \mathrm{s}$ (Table 1, last two columns).

2.4. Inhibition of Self-Induced $\mathrm{A} \boldsymbol{\beta}$ Aggregation and Cholinesterases. In vitro inhibition of $\mathrm{A} \beta_{40}$ aggregation was assessed following a previously reported thioflavin $\mathrm{T}$ (ThT) fluorescence-based method involving the use of hexafluoroisopropanol (HFIP) as aggregation enhancer. For the most active compounds ( $\geq 80 \% \mathrm{~A} \beta$ aggregation inhibition) $\mathrm{IC}_{50}$ values were determined under the same assay conditions as previously described. ${ }^{41}$ Inhibitory activities on AChE from electric eel (eeAChE) and $\mathrm{BChE}$ from equine serum (esBChE) were determined by the spectrophotometric method of Ellman ${ }^{42}$ and are reported in Table 2 as $\mathrm{IC}_{50}(\mu \mathrm{M})$ for the most active compounds or as percentage of inhibition at 10 $\mu \mathrm{M}$ for low active (i.e., $<50 \%$ ) compounds.

At a concentration of $100 \mu \mathrm{M}$, all the compounds 1-14 were proved to inhibit $\mathrm{A} \beta$ aggregation, mostly showing $\mathrm{IC}_{50}$ values in the range of $1.9-19 \mu \mathrm{M}$. Among them, eight (2-9) and three $(11,12$, and 14) were naphthoquinone and anthraquinone derivatives, respectively. The compounds 1, 10, and 13 exhibited an $\mathrm{A} \beta$ inhibition rate of about $60 \%$ at a concentration of $100 \mu \mathrm{M}$. The size of the aromatic bi- and tricyclic system seems to influence the biological effect, as the most potent compounds (12 and 11) sharing $\mathrm{IC}_{50}$ values equal to 1.9 and $2.1 \mu \mathrm{M}$, respectively, belong to the anthraquinone series. Previous studies have demonstrated the capability of (hetero)aromatic tricyclic systems to establish stronger interactions (hydrophobic and electrostatic) with the amino acid sequence $\mathrm{H}_{14} \mathrm{QKLVFF}_{20}$ of $\mathrm{A} \beta$, which is more prone to aggregating. ${ }^{43}$ The length of spacer between the quinone scaffolds and the (hetero)aromatic rings influenced the biological activity with a different trend in the two series; that is, one methylene unit was found as the optimal distance for naphthoquinone-based derivatives (compare aryl derivatives 2-4), while for anthraquinones the increase of the carbon units from 1 to 3 (compare derivatives 10-12) resulted in a proportional increase of the inhibition potency against $\mathrm{A} \beta$ aggregation. Regarding the naphthoquinones linked to a heterocyclic skeleton, the activities of the indole $\left(5, \mathrm{IC}_{50}=\right.$ $6.6 \mu \mathrm{M})$ and benzotriazole $\left(7, \mathrm{IC}_{50}=8.7 \mu \mathrm{M}\right)$ derivatives were comparable and about 2 -fold higher than that of benzimidazole derivative (6). Consequently, the presence of a hydrogen bond donor group such as the $\mathrm{NH}$ group of indole ring rather than a hydrogen bond acceptor feature as experienced by the $\mathrm{N}(2)$ atom of the benzotriazole ring was permitted, allowing the yield of the same degree of activity. In silico studies previously highlighted the marginal role of $\mathrm{NH}$ indole in the tryptophan derivative 9, since its $\mathrm{N}$-methylation did not affect the binding affinity to amyloid oligomers, while its $\mathrm{NH}$ group on naphthoquinone $\mathrm{C}(2)$ and its $\mathrm{CO}$ group of carboxylic function were reported as essential features for the inhibition of $\mathrm{A} \beta$ aggregation. $^{44}$ Our experimental data, however, pointed out that compound 5, lacking in the $\mathrm{COOH}$ function, was 2-fold 
Table 2. Inhibitory Activities ${ }^{a}(\mu \mathrm{M})$ of the Investigated Compounds 1-14 against A $\beta$ Aggregation, ChEs, and MAOs

\begin{tabular}{|c|c|c|c|c|c|}
\hline \multirow[b]{2}{*}{ compd } & \multicolumn{5}{|c|}{$\mathrm{IC}_{50}(\mu \mathrm{M})$ or $(\% \text { inhibition })^{b}$} \\
\hline & $\mathrm{A} \beta_{40}$ aggr & $e e \mathrm{AChE}$ & esBChE & $h \mathrm{MAO} \mathrm{A}$ & $h \mathrm{MAO} \mathrm{B}$ \\
\hline 1 & $(63 \pm 3)^{c}$ & $(39 \pm 1)$ & $(8 \pm 3)$ & $(<5)$ & $(22 \pm 4)$ \\
\hline 2 & $3.2 \pm 0.8$ & $9.2 \pm 0.6$ & $(26 \pm 3)$ & $3.6 \pm 0.3$ & $0.0077 \pm 0.0013$ \\
\hline 3 & $4.4 \pm 0.3$ & $7.9 \pm 0.8$ & $(24 \pm 1)$ & $(41 \pm 3)$ & $0.031 \pm 0.001$ \\
\hline 4 & $8.2 \pm 0.3$ & $3.5 \pm 0.3$ & $(35 \pm 3)$ & $3.0 \pm 0.2$ & $0.054 \pm 0.001$ \\
\hline 5 & $6.6 \pm 0.1$ & $8.7 \pm 0.8$ & $(29 \pm 4)$ & $5.0 \pm 0.2$ & $0.11 \pm 0.01$ \\
\hline 6 & $19 \pm 4$ & $6.8 \pm 0.7$ & $(24 \pm 4)$ & $(23 \pm 4)$ & $(24 \pm 6)$ \\
\hline 7 & $8.7 \pm 0.4$ & $1.7 \pm 0.1$ & $(15 \pm 3)$ & $(21 \pm 6)$ & $0.48 \pm 0.08$ \\
\hline 8 & $17 \pm 2$ & $13 \pm 2$ & $(14 \pm 3)$ & $(26 \pm 6)$ & $2.7 \pm 0.8$ \\
\hline 9 & $14 \pm 2$ & $11 \pm 1$ & $(17 \pm 1)$ & $(22 \pm 2)$ & $(52 \pm 3)$ \\
\hline 10 & $(62 \pm 2)^{c}$ & $8.7 \pm 0.5$ & $(24 \pm 3)$ & $1.1 \pm 0.3$ & $(34 \pm 3)$ \\
\hline 11 & $2.1 \pm 0.2$ & $7.3 \pm 0.7$ & $1.7 \pm 0.3$ & $3.1 \pm 0.3$ & $0.57 \pm 0.02$ \\
\hline 12 & $1.9 \pm 0.3$ & $7.84 \pm 0.03$ & $8.2 \pm 0.4$ & $(50 \pm 3)$ & $0.24 \pm 0.05$ \\
\hline 13 & $(57 \pm 5)^{c}$ & $1.85 \pm 0.04$ & $(17 \pm 1)$ & $(25 \pm 5)$ & $(42 \pm 1)$ \\
\hline 14 & $11 \pm 2$ & $8.1 \pm 0.5$ & $3.4 \pm 0.2$ & $(53 \pm 3)$ & $0.98 \pm 0.14$ \\
\hline quercetin & $0.82 \pm 0.07$ & & & & \\
\hline donepezil & & $0.021 \pm 0.002$ & $2.3 \pm 0.1$ & & \\
\hline safinamide & & & & $(18 \pm 3)$ & $0.031 \pm 0.001$ \\
\hline
\end{tabular}

${ }^{a}$ Data are the mean \pm SEM of $n=3$ experiments. ${ }^{b}$ Data in parentheses correspond to $\%$ of inhibition at $10 \mu \mathrm{M}$, or ${ }^{c} 100 \mu \mathrm{M}$ for inhibition of $\mathrm{A} \beta_{40}$ aggregation.

more effective than the amino acid analogue 9 such as $\mathrm{A} \beta$ aggregation inhibitor. The same potencies trend was observed for analogues 3 and $\mathbf{8}$, whereas the presence of the polar carboxylic group in the phenylalanine derivative 8 negatively impaired the activity. Our results corroborate the suitability of naphthoquinone and anthraquinone scaffolds in providing $\mathrm{A} \beta$ peptide inhibition, even more when properly substituted with hydrophobic moieties able to target the aromatic interactions occurring in the amyloid self-assembly process. Such behavior was confirmed by AFM studies, as shown below.

By comparison of compounds 1-14 with our first series of naphthoquinone and anthraquinones bearing a basic side chain (Figure 1), in the case of naphthoquinones the activity improved with 8 out of 9 compounds able to target $\mathrm{A} \beta$ peptide, while the anthraquinones exhibited only a slight increase of the potency but with a reduced number of active compounds. Therefore, the more apolar nature of the side chain (aromatic/ heteroaromatic moiety), in place of polar basic groups, emerged as a relevant factor in enhancing the intrinsic capability of naphthoquinone and anthraquinone scaffolds to target $\mathrm{A} \beta$ fibrillation.

Apart from the phenylamino naphthoquinone 1 , all the compounds have also been proven to inhibit $\mathrm{AChE}$ reaching a low micromolar potency range. Conversely, $\mathrm{BChE}$ has been found to be less sensitive to these series of compounds except for the anthraquinone derivatives 11,12 , and 14 whose $\mathrm{IC}_{50}$ ranged from 1.7 to $8.2 \mu \mathrm{M}$. The most potent and selective AChE inhibitors were the benzotriazole-based naphthoquinone $7\left(\mathrm{IC}_{50}=1.7 \mu \mathrm{M}\right)$ and the indole-based anthraquinone 13 $\left(\mathrm{IC}_{50}=1.85 \mu \mathrm{M}\right)$, while the anthraquinone derivatives 11 and 12 behaved as dual cholinesterase inhibitors; in particular, compound 11 exhibited a comparable potency profile toward the two enzymes, while 12 was 2.5 -fold more selective for BChE. In general, the new substitution pattern explored in the present series of naphthoquinone and anthraquinone derivatives on one hand positively ameliorated the inhibitory potency against $\mathrm{A} \beta$ aggregation and on the other hand was responsible for a reduced efficacy against cholinesterases, especially BChE, in comparison to the previous series (Figure 1) which were shown to be more potent dual inhibitors of both enzymes. ${ }^{16}$

2.5. Inhibition of hMAOs. MAO inhibition was performed with a routine spectrophotometric assay, monitoring the fluorescence of 4-hydroxyquinoline produced in the MAO-catalyzed oxidation of kynuramine. ${ }^{45}$ With few exceptions, the title compounds acted as selective MAO B inhibitors, thus corroborating their potential as multitarget anti- $\mathrm{AD}$ agents, with $\mathrm{IC}_{50}$ values in the submicromolar range (Table 2). It is worthy to note the high potency of $N$-arylalkyl substituted naphthoquinones $\mathbf{2 - 4}$, whose $\mathrm{IC}_{50}$ values lay in the nanomolar range. Benzylamine derivative 2 , with $\mathrm{IC}_{50}$ equal to $7.7 \mathrm{nM}$, resulted in a potency higher than reference drug safinamide, while 11 and 12 , homologues of 3 and 4 , were the most potent MAO B inhibitors within the anthraquinone series. Compared with phenethyl derivative 3, the substitution of phenyl with indole (5) retained good potency, while the introduction of different heteroaromatic systems was somehow detrimental.

The very high potency of naphthoquinone $\mathbf{2}$ deserved further biochemical investigation in order to clarify its inhibition mechanism. Preliminarily we confirmed that MAO $B$ inhibition was not the consequence of a pan-assay interference of 2 in the fluorimetric assay, ${ }^{46}$ by performing the same kynuramine-based assay in spectrophotometric mode, following the increase of absorbance of 4-hydroxyquinoline at $316 \mathrm{~nm}^{47}$ An $\mathrm{IC}_{50}$ equal to $18 \mathrm{nM}$ was obtained, in good agreement with that reported in Table 2. Concerning the inhibition mechanism, we detected a competitive inhibition (inhibition constant $K_{\mathrm{i}}=22 \mathrm{nM}$ ) when the coincubation with enzyme was limited to $5 \mathrm{~min}$ (Figure S2). For higher coincubation times (up to $2 \mathrm{~h}$ ) the mechanism apparently turned noncompetitive, with the $K_{\mathrm{i}}$ increasing about 20 -fold. This change could be ascribed to the formation of a covalent complex with the N5 of flavin, ${ }^{48}$ due to the presence of the chlorine leaving group. Indeed, a time course of absorption of 4-hydroxyquinoline at $316 \mathrm{~nm}$ revealed that the enzymatic activity was still present even after $3 \mathrm{~h}$ in the presence of 10 nM 2 (Figure 3). This activity profile was quite comparable to 

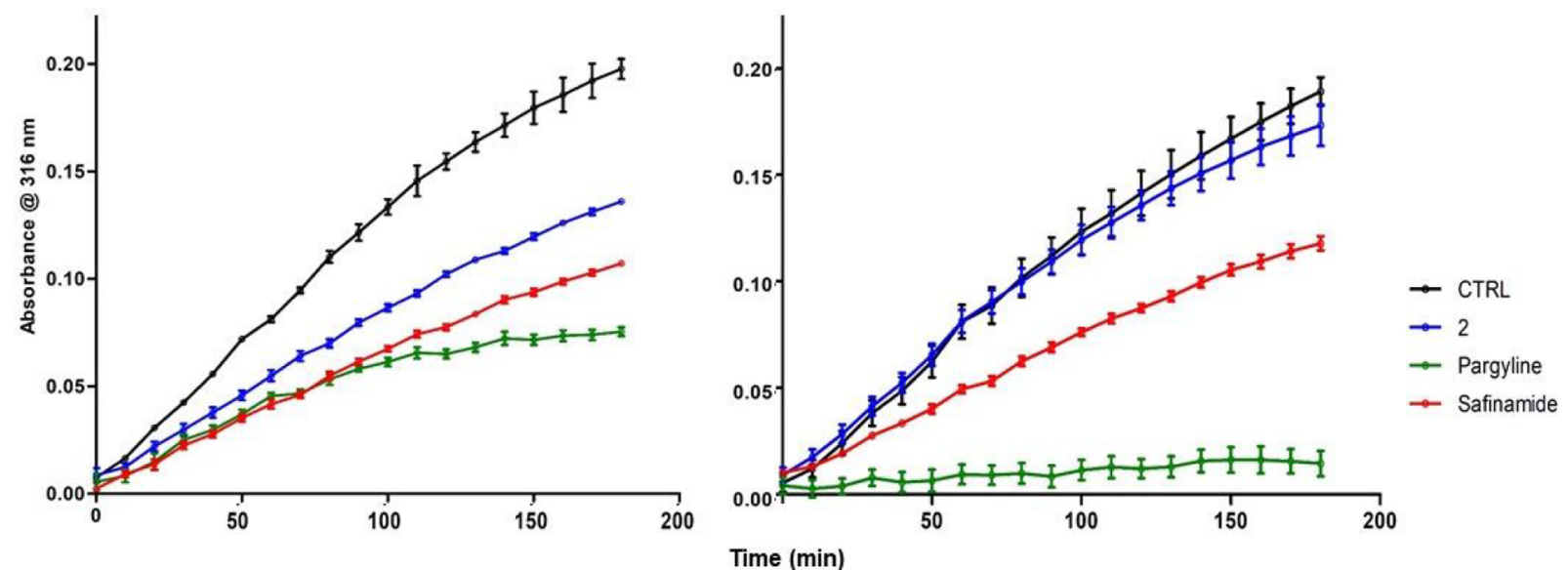

Figure 3. Time course of inhibition of MAO B by 2 ( $10 \mathrm{nM}$, blue line), safinamide (10 nM, red line), and pargyline (100 nM, green line): left, no preincubation; right, $1 \mathrm{~h}$ preincubation with enzyme. Data points represent the absorbance of 4-hydroxyquinoline at $316 \mathrm{~nm}(n=3$; mean $\pm \mathrm{SD})$.
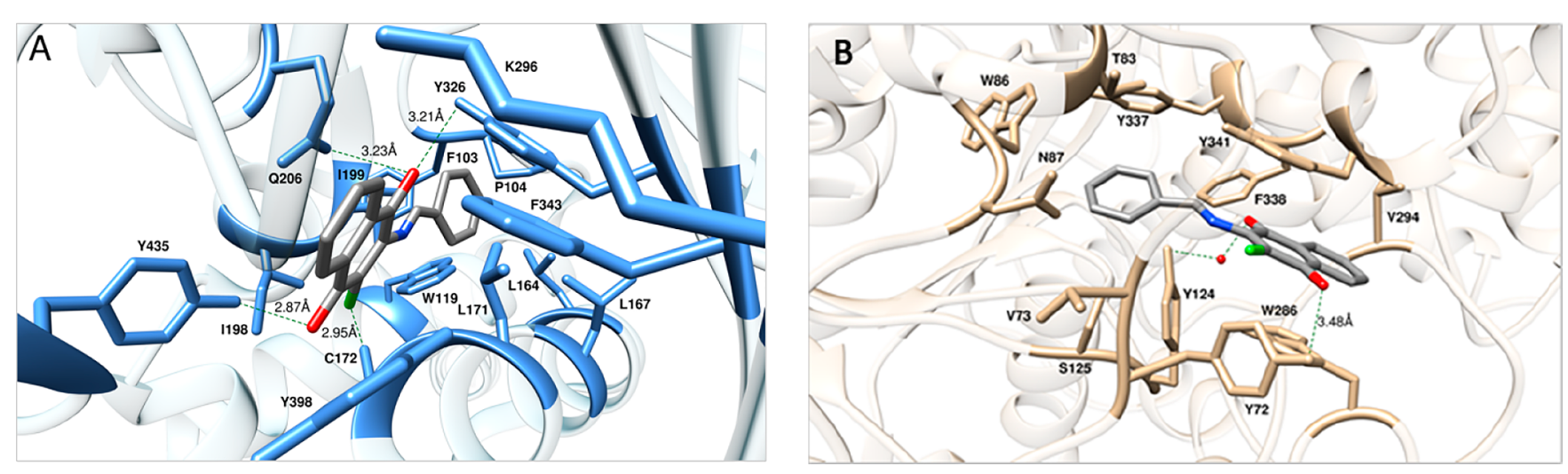

Figure 4. Details of compound 2 in the binding pocket of human MAO B (A) and human AChE (B). Compound 2 is shown as atom-colored sticks ( $\mathrm{C}$, gray; $\mathrm{O}$, red; $\mathrm{N}$, blue; $\mathrm{Cl}$, green), while the side chains of the protein residues mainly interacting with the compound are highlighted as colored sticks and labeled. $\mathrm{HBs} / \mathrm{HaBs}$ are shown as dark green broken lines, and their lengths are indicated $(\AA)$. Hydrogen atoms, water molecules, ions, and counterions are omitted for clarity.
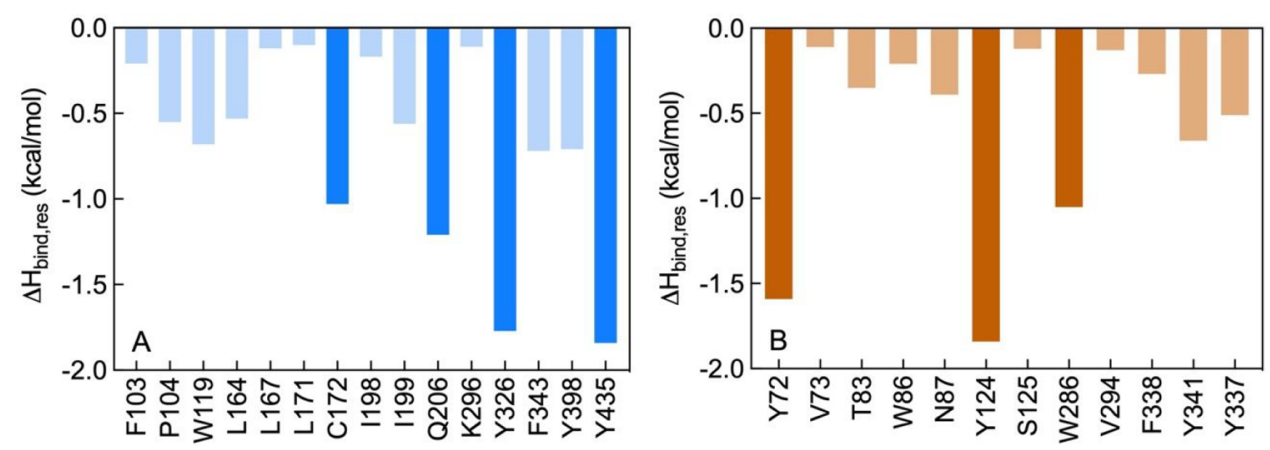

Figure 5. Per residue binding free energy deconvolution (PRBFED) of the enthalpic term $\left(\Delta H_{\text {bind,res }}\right)$ for the MAO B (A) and AChE (B) residues involved in the complex with 2. Dark-colored bars highlights those protein residues involved in stronger interactions (e.g., HBs) with the compound in each complex.

that of $10 \mathrm{nM}$ safinamide, the reference drug for reversible and selective MAO B inhibition, when the assay was performed without preincubation with the enzyme (Figure 3, left). With a preincubation of $1 \mathrm{~h}$, the time course of MAO B activity was still comparable for $\mathbf{2}$ and safinamide, although $\mathbf{2}$ suffered a strong decrease of potency (Figure 3, right). When incubated with $100 \mathrm{nM}$ pargyline, a known irreversible MAO B inhibitor, the MAO B kinetic profiles were clearly different, since the enzymatic activity in the presence of pargyline came to saturation in about $1 \mathrm{~h}$ (Figure 3, left) and was completely inhibited with the preincubation (Figure 3, right). We speculate that the time-dependent change in potency of compound 2 may be due to its inactivation, either from chemical decomposition or from covalent reaction with nucleophilic residues of the enzyme, rather than to the formation of a covalent adduct with the flavin of catalytic site of the enzyme ${ }^{49}$ and by consequence that the inhibition of 2 may be considered as reversible. 
The results listed in Table 2 so far highlighted the naphthoquinone 2 as the molecule endowed with the most effective inhibitory activity against $\mathrm{MAO} B\left(\mathrm{IC}_{50}=7.7 \mathrm{nM}\right)$ and $\mathrm{AChE}\left(\mathrm{IC}_{50}=9.2 \mu \mathrm{M}\right)$. In order to investigate the molecular determinants for the potency and selectivity of 2 toward MAO B and AChE, molecular modeling studies were next performed. Accordingly, the putative binding sites and modes for 2 were first identified on both human enzymes (Figure 4) and then molecular dynamics (MD) simulations of the resulting inhibitor/protein complexes were carried out to evaluate the corresponding free energy of binding $\left(\Delta G_{\text {bind }}\right)$ following our consolidated approach. ${ }^{50-56} \mathrm{~A}$ per-residue binding free energy deconvolution (PRBFED) of the enthalpic $\left(\Delta H_{\text {bind,res }}\right)$ terms ${ }^{50,51}$ was finally performed to define and describe the intermolecular interactions between compound 2 and the two proteins (Figure 5). The simulation results clearly show that $\mathbf{2}$ has a substantially higher affinity for MAO B $\left(\Delta G_{\text {bind }}=-10.98 \pm 0.16 \mathrm{kcal} / \mathrm{mol}\right)$ than for $\operatorname{AChE}\left(\Delta G_{\text {bind }}=\right.$ $-7.93 \pm 0.13 \mathrm{kcal} / \mathrm{mol})$, in agreement with the relevant experimental findings. The inspection of the relevant $\mathrm{MD}$ trajectories reveals that when in complex with MAO B (Figure 4A), the two carbonyl groups of 2 are engaged in two stable hydrogen bonds (HBs) with the monoamine oxidase side chains of $\mathrm{Y} 326(3.21 \pm 0.13 \AA)\left(\Delta H_{\text {bind,res }}=-1.77 \mathrm{kcal} / \mathrm{mol}\right.$, Figure 5A) and Y435 $(2.87 \pm 0.11 \AA)\left(\Delta H_{\text {bind,res }}=-1.84 \mathrm{kcal} /\right.$ mol, Figure $5 \mathrm{~A})$, respectively. Moreover, one of the $-\mathrm{C}=\mathrm{O}$ groups of 2 is also permanently $\mathrm{H}$-bonded with the $--\mathrm{NH}_{2}$ moiety of MAO B Q206 $(3.23 \pm 0.13 \AA)\left(\Delta H_{\text {bind,res }}=-1.21\right.$ $\mathrm{kcal} / \mathrm{mol}$, Figure $5 \mathrm{~A}$ ), while the chlorine atom of 2 interacts via a halogen bond $(\mathrm{HaB})$ with the thiol group of MAO B C172 at an optimal distance of $2.95 \pm 0.11 \AA\left(\Delta H_{\text {bind,res }}=-1.03 \mathrm{kcal} /\right.$ $\mathrm{mol}) .{ }^{57}$ In addition, the $2 / \mathrm{MAO} \mathrm{B}$ complex is further stabilized in the putative binding site through an extended network of close van der Waals/hydrophobic contact interactions (CIs) between the ligand and the side chains of MAO B residues F103, P104, W119, L164, L167, L171, I198, I199, K296, F343, and $\mathrm{Y} 398\left(\sum \Delta H_{\text {bind,res }}=-4.46 \mathrm{kcal} / \mathrm{mol}\right.$, Figure $\left.5 \mathrm{~A}\right)$, as highlighted in panel A of Figure 4.

On the other hand, within the putative binding site of AChE the naphthoquinone core of $\mathbf{2}$ is involved in a $\pi-\pi$ interaction with AChE W286 $\left(\Delta H_{\text {bind,res }}=-1.05 \mathrm{kcal} / \mathrm{mol}\right.$, Figure $\left.5 \mathrm{~B}\right)$ and is further stabilized by weak CIs with the side chains of the esterase residues V294, F338, and Y341 $\left(\sum \Delta H_{\text {bind,res }}=-1.36\right.$ $\mathrm{kcal} / \mathrm{mol}$, Figure $5 \mathrm{~B})$. One of the two $-\mathrm{C}=\mathrm{O}$ groups of 2 directly engages the side chain of $\mathrm{Y} 72$ in a long but stable $\mathrm{HB}$ $(3.48 \pm 0.22 \AA)\left(\Delta H_{\text {bind,res }}=-1.59 \mathrm{kcal} / \mathrm{mol}\right.$, Figure $\left.5 \mathrm{~B}\right)$, while the second carbonyl moiety interacts with the $-\mathrm{OH}$ group of AChE Y124 via a water-mediated $\mathrm{HB}(2.40 \pm 0.33$ $\left.\left(2 \cdots \mathrm{H}_{2} \mathrm{O}\right), 2.38 \pm 0.36 \AA\left(\mathrm{Y} 124 \cdots \mathrm{H}_{2} \mathrm{O}\right)\right)\left(\Delta H_{\text {bind,res }}=-1.84\right.$ $\mathrm{kcal} / \mathrm{mol}$, Figure $5 \mathrm{~A}$ ). Additionally, mildly favorable, unspecific contacts are detected between the phenyl moiety of $\mathbf{2}$ and AChE residues V73, T83, W86, N87, S125, and Y337 $\left(\sum \Delta H_{\text {bind,res }}=-1.69 \mathrm{kcal} / \mathrm{mol}\right.$, Figure $\left.5 \mathrm{~B}\right)$. Accordingly, the interactions between 2 and $\mathrm{AChE}$ are definitely less optimized than those detected in the alternative 2/MAO B complex and provide a molecular-based rationale for the weaker $(\mu \mathrm{M})$ and stronger (nM) affinity of $\mathbf{2}$ for the esterase and the monoamino oxidase, respectively.

2.6. Inhibition of PHF6 Aggregation. New evidence has shifted our understanding about the role of tau in $\mathrm{AD}$ pathogenesis, acting as crucial partner of $\mathrm{A} \beta .^{58}$ The intracellular binding of soluble $\mathrm{A} \beta$ to nonphosphorylated tau was detected and possibly represents a precursor event to later self- aggregation of both molecules. ${ }^{59} \mathrm{~A} \beta$ has also been shown to affect tau pathology through the upregulation of kinases and proinflammatory cytokines that modulate tau phosphorylation. ${ }^{60}$ The high potency of compounds $\mathbf{1 - 1 4}$ in inhibiting A $\beta$ aggregation prompted us to investigate the same feature in a smart in vitro model of tau aggregation, using as probe the highly repeated sequence (306)VQIVYK(311) (PHF6) responsible for aggregation of tau in paired helical fragments (PHF). ${ }^{61}$ To this aim we developed a fast assay method based on ThT fluorescence. ${ }^{45}$ Results in Figure 6 account for a high

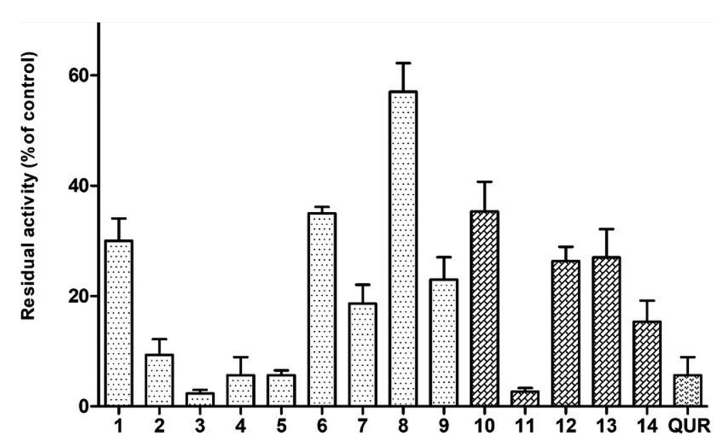

Figure 6. Inhibition of aggregation of PHF6 tau sequence $(50 \mu \mathrm{M})$ by $10 \mu \mathrm{M}$ test molecules. Quercetin (QUR) was used as reference compound. Bars represent the mean $\pm \mathrm{SD}$ of residual aggregation compared with control (CTR). Clear and dark filling patterns are for naphthoquinones and anthraquinones, respectively.

potency profile of the entire set compounds in inhibiting PHF6 aggregation, with inhibition values often $>90 \%$ and comparable to reference drug quercetin. It is worthy of note that phenethyl derivatives 3 and $\mathbf{1 1}$ emerged as the most potent within their structural subsets (inhibition $>95 \%$ ), with $\mathrm{IC}_{50}$ values equal to $4.96 \pm 0.75 \mu \mathrm{M}$ and $1.78 \pm 0.23 \mu \mathrm{M}$, respectively.

2.7. Inhibition of R3 Aggregation. The inhibition exerted by 3 and 11 toward PHF6 aggregation was confirmed in a kinetic experiment of dose-dependent aggregation of peptide R3. The 30-amino acid peptide (V306-Q336) R3 is a high-repeated domain containing the PHF6 sequence and present in all tau isoforms. ${ }^{62}$ Its high propensity to selfaggregate in buffered solutions, even in the absence of aggregation inducers such as heparin, ${ }^{63}$ makes $\mathrm{R} 3$ a reliable surrogate of full-length tau protein for in vitro experiments. In our assay protocol, the commercial R3 peptide was pretreated with 1,1,1-trifluoroethanol (TFE) overnight in order to dissolve any preformed aggregate and reestablish the random coil arrangement, then diluted in PBS at the test concentration of $25 \mu \mathrm{M}$. The R3 aggregation, detected by means of ThT fluorescence, resulted in a sigmoidal time course reaching the plateau after $4 \mathrm{~h}$ of incubation at $37^{\circ} \mathrm{C}$ (Figure 7 ). The plateau values (as \% of control) were used to derive the doseresponse curve for the calculation of $\mathrm{IC}_{50}$ values, which were equal to $1.19 \pm 0.44 \mu \mathrm{M}$ for naphthoquinone 3 and $0.36 \pm$ $0.02 \mu \mathrm{M}$ for anthraquinone 11 .

2.8. Inhibition of $A \beta_{42}$ Fibrillation by ThT Fluorescence Assay. $\mathrm{A} \beta_{42}$ is the main component of circulating amyloid peptides and majorly responsible for neurotoxicity in $\mathrm{AD}$. Its high propensity to self-aggregate allows a fast execution of aggregation assays without the need of aggregation enhancers as for $\mathrm{A} \beta_{40}$. The antiamyloidogenic properties of the newly prepared compounds $\mathbf{1 - 1 4}$ were then tested also for $\mathrm{A} \beta_{42}$ in a coincubation assay at two concentrations (100 and 5 


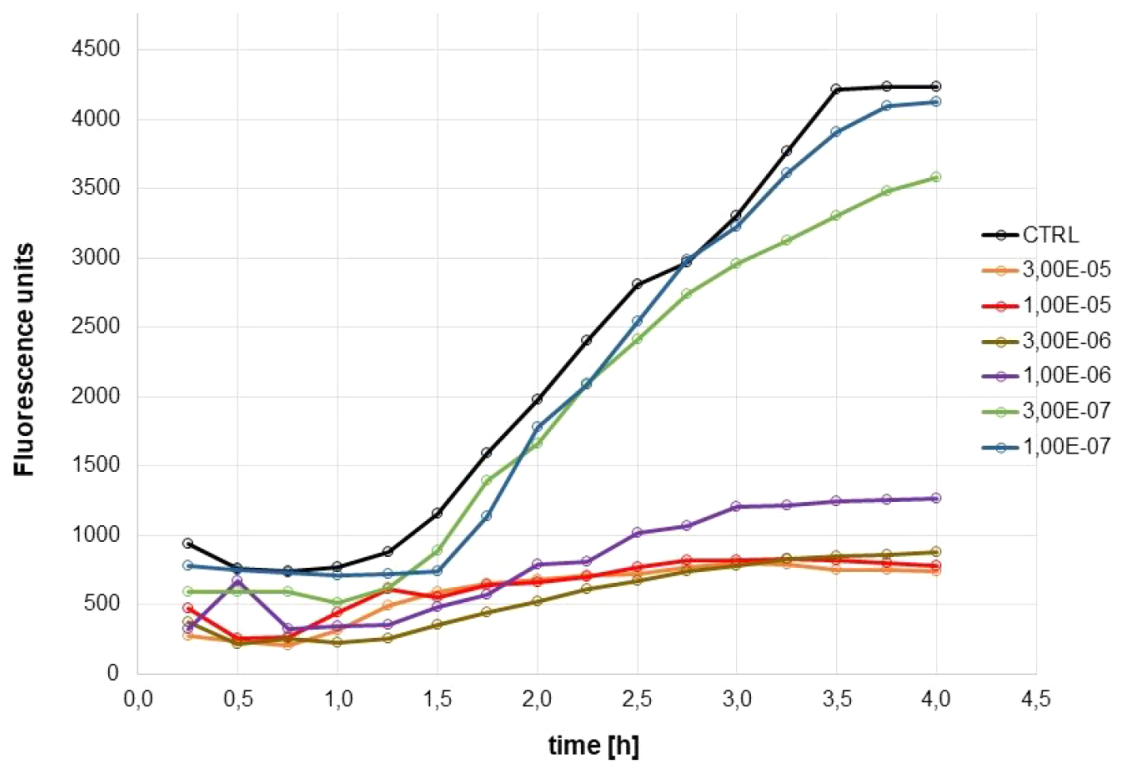

Figure 7. Inhibition of aggregation of $\mathrm{R} 3$ tau sequence $(25 \mu \mathrm{M})$ by 11: time course of aggregation in the presence of six concentrations of 11 (ranging from 30 to $0.1 \mu \mathrm{M}$ ).

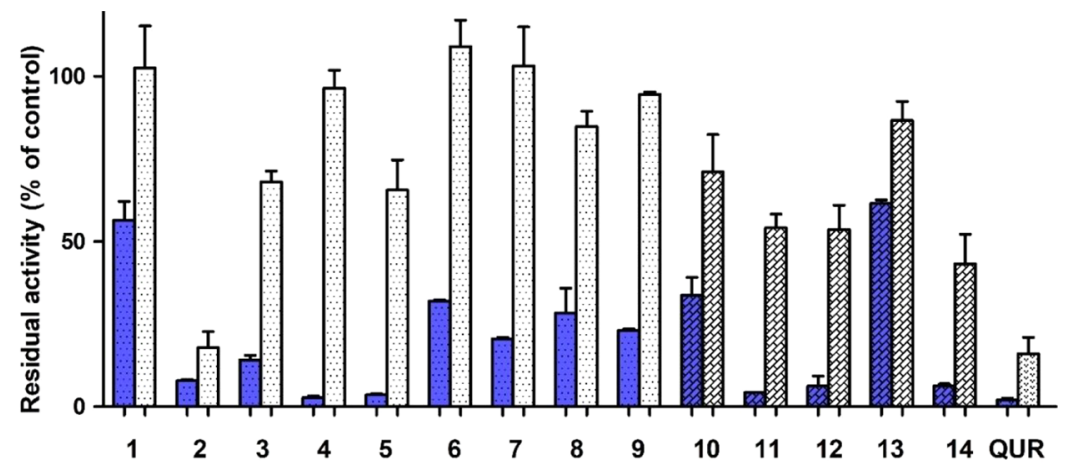

Figure 8. Inhibition of aggregation of $\mathrm{A} \beta_{42}(30 \mu \mathrm{M})$ by $100 \mu \mathrm{M}$ (blue filling) and $5 \mu \mathrm{M}$ (white filling) test molecules. Quercetin (QUR) was used as reference compound. Bars represent the mean $\pm \mathrm{SD}$ of residual aggregation compared with control. Clear and dark filling patterns are for naphthoquinones and anthraquinones, respectively.

$\mu \mathrm{M})$ at $37{ }^{\circ} \mathrm{C}$ for $48 \mathrm{~h}$. Data presented in Figure 8 confirmed the activities already disclosed for $\mathrm{A} \beta_{40}$, with naphthoquinones 2-5 and anthraquinones 11,12 , and 14 displaying the best activity profile. Satisfactorily, compound $\mathbf{2}$ behaved as a strong inhibitor of $\mathrm{A} \beta_{42}$ aggregation even at the lower concentration used, being comparable for potency to quercetin.

2.9. Inhibition of $A \beta_{42}$ Fibrillation Studied by AFM. Among the investigated compounds, the naphthoquinone derivatives $\mathbf{2}$ and $\mathbf{5}$, and the anthraquinone derivatives $\mathbf{1 1}$ and 12 exhibited the highest efficiency against $\mathrm{A} \beta_{40}$ aggregation, as demonstrated by their low $\mathrm{IC}_{50}$ values (Table 2 ). Moreover, they also confirmed their antiamyloidogenic behavior against $\mathrm{A} \beta_{42}$ peptide (Figure 8). Tapping mode atomic force microscopy was then employed to test the ability of this selected subset of compounds to inhibit fibrillation of the highly amyloidogenic fragment $\mathrm{A} \beta_{42}$.

Figure 9 shows representative images of $\mathrm{A} \beta_{42}$ aggregated for $72 \mathrm{~h}$ in fibrillar morphology in the absence (Figure 9A) and in the presence (Figure $9 \mathrm{~B}-\mathrm{E}$ ) of the compounds at a molar ratio 1:2 peptide/compound. The AFM inspection allowed a quantitative evaluation of the number of fibrils per unit area at a fixed aggregation time in the different conditions (Figure 9F). Compared with the control, in the presence of all the investigated compounds a significant decrease of the fibril surface density was observed. The inhibitory effect of the compounds was already observed after $24 \mathrm{~h}$ of aggregation. In fact, although at this stage of aggregation the sample was mainly oligomeric and the number of fibrils was low, in the presence of the compounds there was still a decrease in the fibrils surface density (Figure S3).

2.10. Protection against $\mathbf{A} \boldsymbol{\beta}_{42}$-Induced Toxicity. The most promising MTDLs 2, 5, 11, and $\mathbf{1 2}$ were also tested for their ability to restore cell viability against the toxic effects exerted by $\mathrm{A} \beta_{42}$. Cerebellar granule cells (CGCs) were exposed for $48 \mathrm{~h}$ to $5 \mu \mathrm{M} \mathrm{A} \beta_{42}$ aggregated for $24 \mathrm{~h}$ with and without the compounds (at a molar ratio peptide/compound of 1:2). Cell viability after exposure was measured with the MTT test (Figure 10). Compared with the control, the viability of cells treated with $\mathrm{A} \beta_{42}$ alone decreased to $51 \%$. In the presence of the compounds a partial recovery of the viability was generally observed, with compound $\mathbf{2}$ as the best neuroprotective agent.

The incomplete recovery of cell viability is probably due to the fact that although the compounds are effective in inhibiting aggregation of the peptide, they display some degree of toxicity per se, as at $10 \mu \mathrm{M}$ for any of the test compounds the cell viability remained as high as $\geq 80 \%$ compared to the untreated 

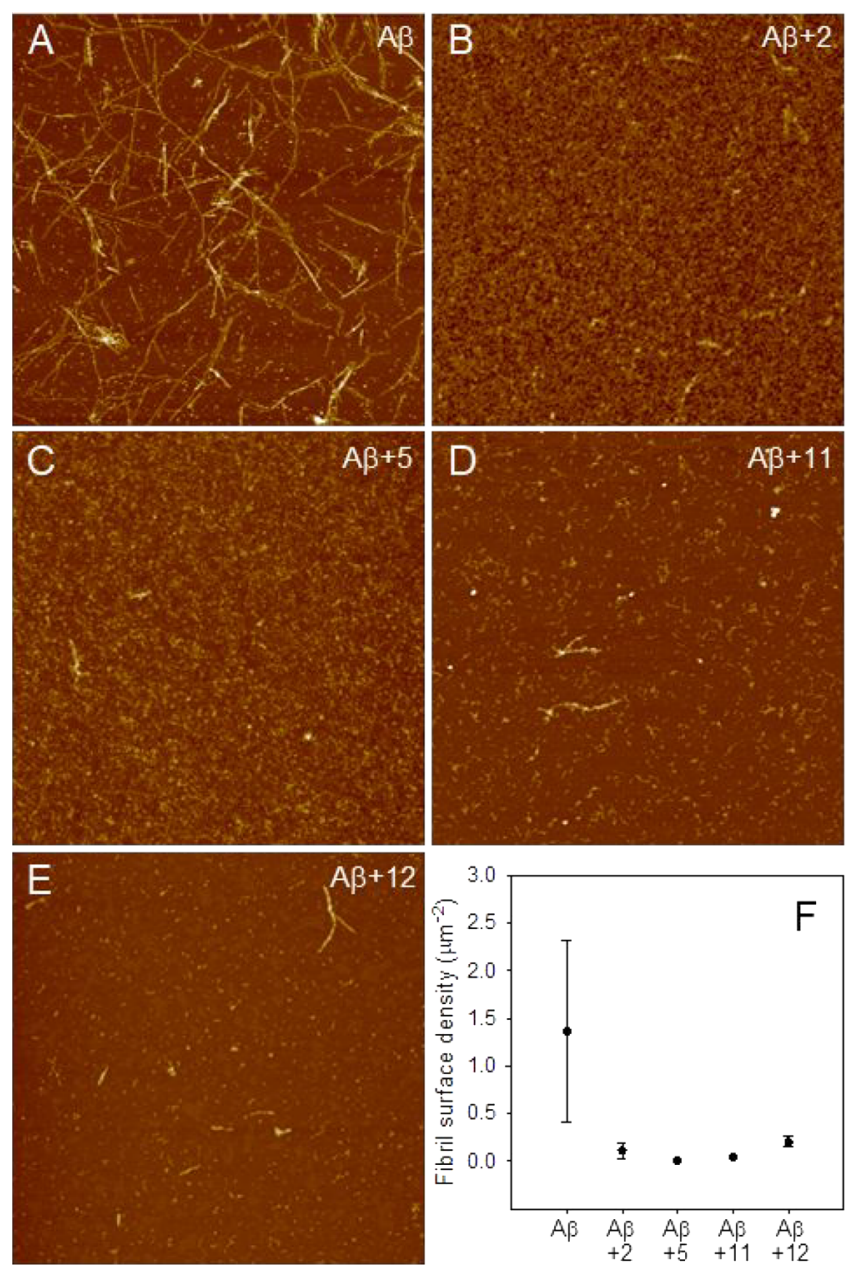

Figure 9. Inhibition of $\mathrm{A} \beta_{42}$ fibrillation tested by AFM. Tapping mode AFM images of $\mathrm{A} \beta_{42}$ after $72 \mathrm{~h}$ of aggregation at room temperature in the absence (A) and in the presence of compounds 2 (B), 5 (C), 11 (D), and 12 (E). Scan size was $5.0 \mu \mathrm{M}$. $Z$ range was $25 \mathrm{~nm}$. (F) Quantitative evaluation of the fibril surface density (number of fibrils per unit area) in the absence and in the presence of the compounds. Mean values obtained on at least six different areas of $100 \mu \mathrm{m}^{2}$ are reported. Errors were calculated using Student's statistics, assuming a confidence level of $95 \%$.

control cells (Table 3). However, on the whole, the biological results indicate for these molecules a rather narrow safety margin (as the ratio toxicity/activity), especially considering that most of their activities are in the micromolar range. For a more meaningful assessment of the value of the present compounds, the issue of their toxicity, in comparison to established drugs for $\mathrm{AD}$, should deserve further investigation.

\section{CONCLUSIONS}

The present work demonstrated the promiscuity profile of a novel set of naphthoquinone and anthraquinone-based derivatives able to tackle different factors of interest for the efficient management of $\mathrm{AD}$. These molecules were purportedly designed to inhibit $\mathrm{A} \beta$ aggregation, being properly decorated with hydrophobic moieties able to target the aromatic interactions implicated in amyloid self-assembly. In agreement with the design rationale the compounds significantly inhibited $\mathrm{A} \beta_{40}$ aggregation and more interestingly the most active derivatives $(\mathbf{2}, \mathbf{5}, \mathbf{1 1}$, and $\mathbf{1 2})$ were confirmed to disrupt fibrillation of the highly amyloidogenic fragment $\mathrm{A} \beta_{42}$.
All the compounds exhibited a preferential inhibition of AChE than $\mathrm{BChE}$ and appeared to be efficient inhibitors of fastaggregating tau peptides PHF6 and R3. Moreover, most of them turned out to be potent and selective MAO B inhibitors, being able to provide $\mathrm{IC}_{50}$ values in the nanomolar or submicromolar range with respect to the less sensitive MAO A isoform. Outstandingly, compound $\mathbf{2}$ exhibited a remarkable inhibitory activity against MAO B $\left(\mathrm{IC}_{50}=7.7 \mathrm{nM}\right)$ which was 473-fold higher than that versus MAO A. MAO enzymes significantly contribute to the selective degeneration of noradrenergic and cholinergic neurons in $\mathrm{AD}$ brains $^{25}$ and through the formation of reactive aldehydes that showed facilitation of the conversion of $\beta$-amyloid to the hydrophobic $\beta$-sheet conformation and subsequent fibrillogenesis in vitro. ${ }^{64}$ It is worth noting that a comparable SAR trend was observed between the previously discussed inhibition of self-induced $\mathrm{A} \beta$ aggregation and $\mathrm{MAO}$, thus suggesting a potential correlation between the two inhibition mechanisms. Finally, these MTDL molecules were also found to ameliorate the cytotoxicity caused by $\mathrm{A} \beta_{42}$ peptide. Collectively, these results indicate that our series of naphthoquinone and anthraquinone derivatives possess antiamyloidogenic properties and a multitarget profile, thus enabling them as valuable candidates for $\mathrm{AD}$ therapy.

\section{METHODS}

4.1. Chemistry. 4.1.1. General Methods. Chemicals and solvents were purchased from Sigma-Aldrich (Milan, Italy). Melting points were measured using a Büchi apparatus and were uncorrected. ${ }^{1} \mathrm{H}$ NMR spectra and ${ }^{13} \mathrm{C}$ NMR spectra were recorded on a Varian Gemini-200 instrument at 200 and $50 \mathrm{MHz}$, respectively. Chemical shifts are reported as $\delta(\mathrm{ppm})$ and are referenced to a solvent signal: $\mathrm{CDCl}_{3}$, singlet at $7.26 \mathrm{ppm}\left({ }^{1} \mathrm{H}\right)$, triplet at $77.0 \mathrm{ppm}\left({ }^{13} \mathrm{C}\right)$; DMSO$d_{6}$, quintet at $2.5 \mathrm{ppm}\left({ }^{1} \mathrm{H}\right)$, septet at $39.5 \mathrm{ppm}\left({ }^{13} \mathrm{C}\right) . J$ is in $\mathrm{Hz}$. Elemental analyses were performed on a Flash 2000 CHNS (Thermo Scientific) instrument in the Microanalysis Laboratory of the Department of Pharmacy, University of Genoa. NMR spectra of the novel compounds are shown in the Supporting Information. Results of elemental analyses indicated that the purity of all compounds was $\geq 95 \%$.

4.1.2. General Method for the Synthesis of Naphthoquinone Derivatives (4-7). A mixture of appropriate amine (5 mmol) and 2,3dichloronaphthoquinone $1(2.5 \mathrm{mmol})$ in absolute ethanol $(20 \mathrm{~mL})$ was stirred under reflux for $4 \mathrm{~h}$ with stirring. In the case of compounds 5-7 the reaction mixture was stirred at room temperature for $24 \mathrm{~h}$. During the progress of the reaction, monitored by TLC, a change in the color from yellow to red was observed. After evaporation of the solvent, the residue was treated with a solution of $2 \mathrm{~N} \mathrm{NaOH}$ and $\mathrm{CHCl}_{3}$. The layers were separated, and the chloroform solution was dried $\left(\mathrm{Na}_{2} \mathrm{SO}_{4}\right)$, filtered, and evaporated, affording a residue that was purified by $\mathrm{CC}\left(\mathrm{SiO}_{2}, \mathrm{CHCl}_{3}+2 \% \mathrm{MeOH}\right)$.

4.1.2.1. 2-Chloro-3-(phenylpropylamino)-1,4-naphthoquinone (4). Yield: $75 \%$. Mp $94-96{ }^{\circ} \mathrm{C} .{ }^{1} \mathrm{H}$ NMR (200 MHz, $\left.\mathrm{CDCl}_{3}\right) \delta$ : $8.40-8.00(\mathrm{~m}, 2 \mathrm{H}$, arom); 7.84-7.58 (m, $2 \mathrm{H}$, arom); 7.41-7.18 (m, $5 \mathrm{H}$, arom $) ; 6.15(\mathrm{~s}, 1 \mathrm{H}, \mathrm{NH}) ; 3.90(\mathrm{q}, J=7 \mathrm{~Hz}, 2 \mathrm{H}$, $\left.\mathrm{NHCH}_{2} \mathrm{CH}_{2} \mathrm{CH}_{2} \mathrm{Ar}\right) ; 2.77\left(\mathrm{t}, J=7.6 \mathrm{~Hz}, 2 \mathrm{H}, \mathrm{NHCH}_{2} \mathrm{CH}_{2} \mathrm{CH}_{2} \mathrm{Ar}\right)$; 2.07 (quint, $\left.J=6.8 \mathrm{~Hz}, 2 \mathrm{H}, \mathrm{NHCH}_{2} \mathrm{CH}_{2} \mathrm{CH}_{2} \mathrm{Ar}\right) .{ }^{13} \mathrm{C} \mathrm{NMR}(50$ $\left.\mathrm{MHz}, \mathrm{CDCl}_{3}\right) \delta: 179.4,175.8,143.0,139.7,133.9,131.7,131.4$, 128.6, 127.5, 127.3, 125.8, 125.2, 43.2, 31.8, 31.5. Anal. Calcd for $\mathrm{C}_{19} \mathrm{H}_{16} \mathrm{ClNO}_{2}$ : C 70.05; H 4.95; N 4.30. Found: C 70.30; H 5.17; N 4.17 .

4.1.2.2. 2-[2-(1H-Benzimidazol-1-yl)ethylamino]-3-chloro-1,4naphthoquinone (6). Yield: $49 \%$. Mp $205-207{ }^{\circ} \mathrm{C} .{ }^{1} \mathrm{H}$ NMR (200 $\left.\mathrm{MHz}, \mathrm{CDCl}_{3}\right) \delta: 8.22$ (s, $1 \mathrm{H}$, arom); 7.88 (s, $1 \mathrm{H}$, arom); 7.58-7.18 (m, 4H, arom); 6.98-6.77 (m, $1 \mathrm{H}$ arom); 6.76-6.42 (m, $2 \mathrm{H}$, arom); 6.24 (broad s, $1 \mathrm{H}, \mathrm{NH}) ; 3.70-3.40\left(\mathrm{~m}, 2 \mathrm{H}, \mathrm{NHCH}_{2} \mathrm{CH}_{2}-\right.$ $\mathrm{N}(1)$ Benz); 3.34-2.98 (m, $2 \mathrm{H}, \mathrm{NHCH}_{2} \mathrm{CH}_{2}$-(N1)Benz). ${ }^{13} \mathrm{C} \mathrm{NMR}$ $\left(50 \mathrm{MHz}, \mathrm{CDCl}_{3}\right) \delta: 172.9,153.6,142.7,140.0,137.6,131.4,129.6$, 


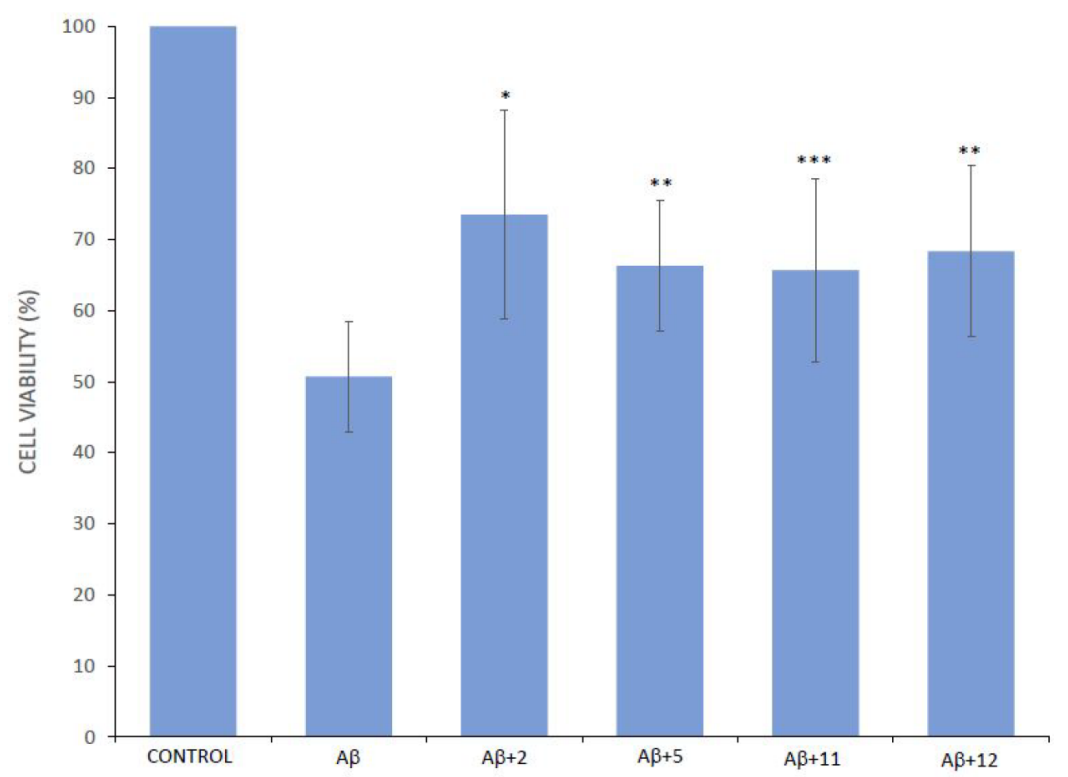

Figure 10. Protection against $\mathrm{A} \beta_{42}$ toxicity in cerebellar granule cells. The CGCs were treated with vehicle (control) or with $\mathrm{A} \beta_{42}$, with or without the tested compounds, for $48 \mathrm{~h}$. Cell viability was measured by MTT reduction test and expressed as loss of viability in comparison with vehicletreated controls. Values have been obtained from at least three experiments. Compound $\mathrm{A} \beta$ vs $\mathrm{A} \beta$ : $* p<0.01, * *_{p}<0.02, * * *<0.05$.

Table 3. In Vitro Cytotoxicity of Compounds 2, 5, 11, $12^{a}$

\begin{tabular}{ccccc} 
& \multicolumn{4}{c}{} \\
\cline { 2 - 5 } compound & $\mathbf{2}$ & $\mathbf{5}$ & $\mathbf{1 1}$ & $\mathbf{1 2}$ \\
$\begin{array}{c}\text { cell viability vs control } \\
(\%)\end{array}$ & $89 \pm 14$ & $85 \pm 14$ & $85 \pm 15$ & $77 \pm 12$
\end{tabular}

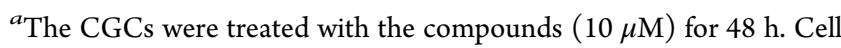
viability was measured by MTT reduction test and expressed as loss of viability in comparison with vehicle-treated controls. Values have been obtained from at least three experiments. Data are expressed as the mean \pm SEM.

128.5, 124.5, 124.0, 121.9, 118.5, 112.0, 105.6, 48.5, 44.9. Anal. Calcd for $\mathrm{C}_{19} \mathrm{H}_{14} \mathrm{ClN}_{3} \mathrm{O}_{2}$ : C 64.87; H 4.01; N 11.94. Found: C 64.63; $\mathrm{H}$ 4.28; N 12.06.

4.1.2.3. $2-\{[2-(1 \mathrm{H}$-Benzotriazol-1-yl)ethy]amino $\}-3-c h l o r o-1,4-$ naphthoquinone (7). Yield: $39 \%$. Mp $193-194{ }^{\circ} \mathrm{C} .{ }^{1} \mathrm{H}$ NMR (200 $\mathrm{MHz}, \mathrm{DMSO}) \delta$ : 8.05-7.65 (m, 5H, arom); 7.62-7.41 (m, $2 \mathrm{H}$, arom); 7.39-7.23 (m, 1H, arom); $6.29(\mathrm{~s}, 1 \mathrm{H}, \mathrm{NH}) ; 4.98(\mathrm{t}, J=5.8$ $\left.\mathrm{Hz}, 2 \mathrm{H}, \mathrm{NHCH}_{2} \mathrm{CH}_{2}-\mathrm{N}(1) \mathrm{Bzt}\right) ; 4.24(\mathrm{q}, J=6.2 \mathrm{~Hz}, 2 \mathrm{H}$, $\left.\mathrm{NHCH}_{2} \mathrm{CH}_{2} \mathrm{~N}(1) \mathrm{Bzt}\right) .{ }^{13} \mathrm{C}$ NMR (50 MHz, DMSO) $\delta: 179.6$, $174.9,145.2,144.7,134.4,134.2,132.7,132.3,131.1,129.6,126.8$, 126.0, 125.3, 123.5, 118.6, 110.1, 47.8, 43.0. Anal. Calcd for $\mathrm{C}_{18} \mathrm{H}_{13} \mathrm{ClN}_{4} \mathrm{O}_{2}$ : C 61.28; H 3.71; N 15.88. Found: C 61.17; $\mathrm{H}$ 3.77; N 15.98 .

4.1.3. General Method for the Synthesis of Anthraquinone Derivatives (10-14). A mixture of 1-chloroanthraquinone (2.5 $\mathrm{mmol})$ with the suitable amino compound $(2.5 \mathrm{mmol})$ was heated at $160{ }^{\circ} \mathrm{C}$ in a sealed tube for $6 \mathrm{~h}$. After cooling, the mixture was treated with $2 \mathrm{M} \mathrm{NaOH}$ until alkalinity and extracted with $\mathrm{CHCl}_{3}$. After removal of the solvent, the residue was purified by $\mathrm{CC}\left(\mathrm{SiO}_{2} /\right.$ $\left.\mathrm{CHCl}_{3}+2 \% \mathrm{MeOH}\right)$.

4.1.3.1. 1-(Benzylamino)-9,10-anthraquinone (10). Yield: $90 \%$. $\mathrm{Mp} 171-173{ }^{\circ} \mathrm{C} .{ }^{1} \mathrm{H}$ NMR $\left(200 \mathrm{MHz}, \mathrm{CDCl}_{3}\right) \delta: 8.43-8.19(\mathrm{~m}, 2 \mathrm{H}$, arom); 7.96-7.61 (m, 4H, arom); 7.60-7.20 (m, 6H, arom); 7.17$6.98(\mathrm{~m}, 1 \mathrm{H}, \mathrm{NH}) ; 4.62\left(\mathrm{~s}, 2 \mathrm{H}, \mathrm{NHCH}_{2} \mathrm{Ar}\right) .{ }^{13} \mathrm{C} \mathrm{NMR}(50 \mathrm{MHz}$, $\mathrm{CDCl}_{3}$ ) $\delta: 184.2,182.7,150.4,136.9,136.7,134.3,133.9,133.6$, $133.5,132.9,132.6,132.0,127.8,126.5,126.4,126.0,125.7,117.3$, 115.1,112.4, 46.0. Anal. Calcd for $\mathrm{C}_{21} \mathrm{H}_{15} \mathrm{NO}_{2}$ : C 80.49; $\mathrm{H} 4.82$; N 4.47. Found: C 80.11; H 5.20; N 4.17.

4.1.3.2. 1-(Phenethylamino)-9,10-anthraquinone (11). Yield: 71\%. Mp 100-103 ${ }^{\circ} \mathrm{C} .{ }^{1} \mathrm{H}$ NMR (200 MHz, $\left.\mathrm{CDCl}_{3}\right) \delta: 8.42-8.20$ (m, 2H, arom); 7.90-7.70 (m, 2H, arom); 7.68-7.51 (m, 3H, arom); $7.48-7.22(\mathrm{~m}, 5 \mathrm{H}$, arom); $7.11(\mathrm{dd}, 1 \mathrm{H}, J=1.6,6.6 \mathrm{~Hz}, \mathrm{NH}) ; 3.63$ $\left(\mathrm{t}, J=7.2 \mathrm{~Hz}, 2 \mathrm{H}, \mathrm{NHCH}_{2} \mathrm{CH}_{2} \mathrm{Ar}\right) ; 3.10(\mathrm{t}, J=7.8 \mathrm{~Hz}, 2 \mathrm{H}$, $\left.\mathrm{NHCH}_{2} \mathrm{CH}_{2} \mathrm{Ar}\right) .{ }^{13} \mathrm{C}$ NMR $\left(50 \mathrm{MHz}, \mathrm{CDCl}_{3}\right) \delta: 184.0,182.8,150.4$, 137.7, 134.3, 134.0, 133.7, 131.9, 127.7, 126.5, 125.7, 116.7, 114.7, 112.1, 43.6, 34.6. Anal. Calcd for $\mathrm{C}_{22} \mathrm{H}_{17} \mathrm{NO}_{2}$ : C 80.71; H 5.23; N 4.28. Found: C 80.62; H 5.04; N 3.98.

4.1.3.3. 1-[(3-Phenylpropryl)amino]-9,10-anthraquinone (12). Yield: $76 \%$. Mp $115-116{ }^{\circ} \mathrm{C}$. ${ }^{1} \mathrm{H}$ NMR (200 $\left.\mathrm{MHz} \mathrm{CDCl}_{3}\right) \delta$ : 8.42-8.21 (m, 2H, arom); 7.90-7.70 (m, 2H, arom); 7.68-7.48 (m, $2 \mathrm{H}$, arom $) ; 7.42-7.18(\mathrm{~m}, 6 \mathrm{H}$, arom $) ; 7.06(\mathrm{dd}, 1 \mathrm{H}, J=1.6,8.2 \mathrm{~Hz}$, $\mathrm{NH}) ; 3.38\left(\mathrm{t}, J=7.0 \mathrm{~Hz}, 2 \mathrm{H}, \mathrm{NHCH}_{2} \mathrm{CH}_{2} \mathrm{CH}_{2} \mathrm{Ar}\right) ; 2.86(\mathrm{t}, J=7.4$ $\mathrm{Hz}, 2 \mathrm{H}, \mathrm{NHCH}_{2} \mathrm{CH}_{2} \mathrm{CH}_{2} \mathrm{Ar}$ ); 2.15 (quint, $J=7.2 \mathrm{~Hz}, 2 \mathrm{H}$, $\mathrm{NHCH}_{2} \mathrm{CH}_{2} \mathrm{CH}_{2} \mathrm{Ar}$ ). ${ }^{13} \mathrm{C} \mathrm{NMR}\left(50 \mathrm{MHz}, \mathrm{CDCl}_{3}\right.$ ) $\delta: 183.9,182.8$, 150.6, 140.1, 134.2, 133.9, 133.5, 132.9, 131.9, 128.3, 127.5, 127.4, 125.7, 125.6, 125.1, 116.8, 114.6, 111.8, 41.0, 32.1, 29.5. Anal. Calcd for $\mathrm{C}_{23} \mathrm{H}_{19} \mathrm{NO}_{2}$ : C 80.92; H 5.61; N 4.10. Found: C 80.73; H 5.98; N 3.93.

4.1.3.4. 1-\{[2-(1H-Indol-3-yl)ethyl]amino $\}-9,10$-anthraquinone (13). Yield: $40 \%$. Mp $240-241{ }^{\circ} \mathrm{C}$. ${ }^{1} \mathrm{H}$ NMR (200 $\left.\mathrm{MHz}, \mathrm{CDCl}_{3}\right)$ $\delta: 10.84$ (s, $1 \mathrm{H}, \mathrm{NH}$ of indole); 8.18-7.41 (m, 7H, arom); 7.39-6.82 (m, 5H, arom); $6.60(\mathrm{~s}, 1 \mathrm{H}, \mathrm{NH}) ; 3.98$ (pseudo s, $2 \mathrm{H}$, $\mathrm{NHCH}_{2} \mathrm{CH}_{2}$ Ind); 2.99 (pseudo s, $2 \mathrm{H}, \mathrm{NHCH}_{2} \mathrm{CH}_{2}$ Ind). ${ }^{13} \mathrm{C}$ NMR $\left(50 \mathrm{MHz}_{2} \mathrm{CDCl}_{3}\right) \delta: 184.6,182.6,150.0,135.8,134.4,134.2,132.1$, $131.5,130.5,129.5,126.6,126.0,125.3,122.7,120.6,117.9,110.9$, 110.3, 44.2, 33.0. Anal. Calcd for $\mathrm{C}_{24} \mathrm{H}_{18} \mathrm{~N}_{2} \mathrm{O}_{2}$ : C 78.67; H 4.95; N 7.65. Found: C 78.81; H 4.95; N 7.43.

4.1.3.5. 1-\{[2-(1H-Benzotriazol-1-yl)ethyl]amino $\}-9,10-$ anthraquinone (14). Yield: $42 \%$. Mp $176-177{ }^{\circ} \mathrm{C} .{ }^{1} \mathrm{H}$ NMR $(200 \mathrm{MHz}$, $\left.\mathrm{CDCl}_{3}\right) \delta: 8.36-8.15(\mathrm{~m}, 3 \mathrm{H}$, arom); 7.86-7.57 (m, $5 \mathrm{H}$, arom); $7.55-7.22(\mathrm{~m}, 3 \mathrm{H}$, arom); $6.82(\mathrm{~s}, 1 \mathrm{H}, \mathrm{NH}) ; 4.57(\mathrm{t}, J=7.0 \mathrm{~Hz}, 2 \mathrm{H}$, $\left.\mathrm{NHCH}_{2} \mathrm{CH}_{2}-\mathrm{N}(1) \mathrm{Bzt}\right) ; 3.03\left(\mathrm{t}, J=7.0 \mathrm{~Hz}, 2 \mathrm{H}, \mathrm{NHCH}_{2} \mathrm{CH}_{2-}\right.$ $\mathrm{N}(1) \mathrm{Bzt}) .{ }^{13} \mathrm{C} \mathrm{NMR}\left(50 \mathrm{MHz}, \mathrm{CDCl}_{3}\right) \delta: 184.5,183.7,146.2,144.0$, $135.9,133.9,133.4,132.9,132.0,127.8,126.9,125.8,125.0,121.9$, 119.0, 48.5, 44.2. Anal. Calcd for $\mathrm{C}_{22} \mathrm{H}_{16} \mathrm{~N}_{4} \mathrm{O}_{2}$ : C 71.73; $\mathrm{H} 4.38 ; \mathrm{N}$ 15.21. Found: C 71.59; H 4.31; N 15.20.

4.1.4. General Method for the Synthesis of Intermediates: Tryptamine, 2-(Benzimidazol-1-yl)ethylamine, and 2-(Benzotriazol-1-yl)ethylamine. To a suspension of $\mathrm{LiAlH}_{4}(40 \mathrm{mmol})$ in $20 \mathrm{~mL}$ of anhydrous THF cooled at $0-5{ }^{\circ} \mathrm{C}$, a solution of 3-indolylacetamide or 2-(benzimidazol-1-yl)acetonitrile or 2-(benzotriazol-1-yl)acetonitrile $(10 \mathrm{mmol})$ in anhydrous THF $(5 \mathrm{~mL})$ was added drop by drop in $20 \mathrm{~min}$. Then the mixture was refluxed for $8-10 \mathrm{~h}$. At rt 5 
$\mathrm{mL}$ of $\mathrm{H}_{2} \mathrm{O}, 5 \mathrm{~mL}$ of $2 \mathrm{~N} \mathrm{NaOH}$, and $5 \mathrm{~mL}$ of $\mathrm{H}_{2} \mathrm{O}$ were carefully added to the mixture to decompose the excess of $\mathrm{LiAlH}_{4}$, filtering and washing the inorganic residue with $\mathrm{Et}_{2} \mathrm{O}$. The solution was dried with $\mathrm{Na}_{2} \mathrm{SO}_{4}$, filtered, and evaporated to dryness, yielding an orange oil corresponding to the title ethylamino derivative that was chromatographed on $\mathrm{SiO}_{2}$ eluting with $\mathrm{Et}_{2} \mathrm{O}$.

These intermediates were already prepared through different procedures; thus they were characterized as follows.

4.1.4.1. Tryptamine. Yield: $81 \% .{ }^{1} \mathrm{H}$ NMR $\left(200 \mathrm{MHz}, \mathrm{CDCl}_{3}\right) \delta$ : $10.11(\mathrm{~s}, \mathrm{NH}$ of indole), 7.71-7.52 (m, 2H, arom), 7.39-7.20 (m, $2 \mathrm{H}$, arom), 7.16-7.03 (m, 1H, arom), 4.88 (broad s, $\mathrm{NH}_{2}$ ), 3.09$2.95\left(\mathrm{~m}, 4 \mathrm{H}, \mathrm{CH}_{2} \mathrm{CH}_{2}-\mathrm{NH}_{2}\right.$ ). Anal. Calcd for $\mathrm{C}_{10} \mathrm{H}_{12} \mathrm{~N}_{2}: \mathrm{C}$ 74.97; $\mathrm{H}$ 7.55; N 17.48. Found: C 74.81; H 7.95; N 17.23.

4.1.4.2. 2-(Benzimidazol-1-yl)ethylamine. Yield: $76 \%$. ${ }^{1} \mathrm{H}$ NMR $\left(200 \mathrm{MHz}, \mathrm{CDCl}_{3}\right) \delta: 8.21(\mathrm{~s}, 1 \mathrm{H}$, arom), $7.65-7.49(\mathrm{~m}, 2 \mathrm{H}$, arom), 7.35-7.21 (m, $2 \mathrm{H}$, arom), 4.97 (broad s, $\left.\mathrm{NH}_{2}\right), 4.19-4.01(\mathrm{~m}, 2 \mathrm{H}$, $\left.\mathrm{N}-\mathrm{CH}_{2}\right)$, 3.16-3.07 (m, $\left.2 \mathrm{H}, \mathrm{CH}_{2}-\mathrm{NH}_{2}\right)$. Anal. Calcd for $\mathrm{C}_{9} \mathrm{H}_{11} \mathrm{~N}_{3}$ : C 67.06; H 6.88; N 26.07. Found: C 66.91; H 6.79; N 26.31.

4.1.4.3. 2-(Benzotriazol-1-yl)ethylamine. Yield: $76 \% .{ }^{1} \mathrm{H}$ NMR $\left(200 \mathrm{MHz}, \mathrm{CDCl}_{3}\right) \delta: 8.11-7.71(\mathrm{~m}, 2 \mathrm{H}$, arom $), 7.52-7.31(\mathrm{~m}, 2 \mathrm{H}$, arom), 5.01 (broad s, $\mathrm{NH}_{2}$ ), 4.22 (pseudo s, $2 \mathrm{H}, \mathrm{N}-\mathrm{CH}_{2}$ ), 3.45 (pseudo s, $2 \mathrm{H}, \mathrm{CH}_{2}-\mathrm{NH}_{2}$ ). Anal. Calcd for $\mathrm{C}_{8} \mathrm{H}_{10} \mathrm{~N}_{4}$ : C 59.24; $\mathrm{H}$ 6.21; N 34.54. Found: C 59.01; H 6.56; N 34.16.

4.2. Biological Tests. 4.2.1. Inhibition of Self-Induced $A \beta$ Aggregation. $\mathrm{A} \beta_{40}$ and $\mathrm{A} \beta_{42}$ peptides were purchased from EzBiolab, Carmel, IN, USA. In vitro inhibition assay of $\mathrm{A} \beta_{40}$ aggregation has been previously reported ${ }^{41}$ and adapted to a 96 -well plate platform. Briefly, samples of $\mathrm{A} \beta_{40}(30 \mu \mathrm{M})$ were coincubated for $2 \mathrm{~h}$ at $25^{\circ} \mathrm{C}$ with test molecules $(100 \mu \mathrm{M}$ for single point concentration assay, seven concentrations ranging from 100 to $0.1 \mu \mathrm{M}$ for $\mathrm{IC}_{50}$ calculations) in PBS containing 2\% v/v of HFIP.

Inhibition of $\mathrm{A} \beta_{42}$ aggregation was assayed by incubating the peptide $(30 \mu \mathrm{M})$ alone (as the control) or with test compounds (5 or $100 \mu \mathrm{M})$ in PBS at $37^{\circ} \mathrm{C}$ for $48 \mathrm{~h}$.

After incubation in 96-well black, nonbinding microplates (Greiner Bio-One $\mathrm{GmbH}$, Frickenhausen, Germany), thioflavin $\mathrm{T}(25 \mu \mathrm{M})$ was added and fluorimetric reads (ex 440, em $485 \mathrm{~nm}$ ) were performed in a multiplate reader Infinite M1000 Pro (Tecan, Cernusco sul Naviglio, Italy). Experiments were run in triplicate. Results were expressed by statistical analysis while $\mathrm{IC}_{50}$ values were obtained by nonlinear regression using Prism software (GraphPad Prism version 5.00 for Windows, GraphPad Software, San Diego, CA, USA).

4.2.2. Inhibition of Cholinesterases. The classical Ellman's method, modified to a 96-well plate platform, was used as already described. ${ }^{65}$ AChE from electric eel $(463 \mathrm{U} / \mathrm{mL})$, BChE from horse serum $(13 \mathrm{U} / \mathrm{mL})$, acetyl- and butyrylthiocholine, and dithiobis(2nitrobenzoic acid) were purchased from Sigma-Aldrich, Milan, Italy. Experiments were run in triplicate, and inhibition values were obtained by nonlinear regression using Prism software.

4.2.3. Inhibition of Human Monoamine Oxidases. The fluorimetric assays of MAO A and B following the oxidation of kynuramine to 4-hydroxyquinoline (ex 310, em $400 \mathrm{~nm}$ in $\mathrm{NaOH}$ ) were performed as described. ${ }^{45}$ All enzymes and reagents were purchased from Sigma-Aldrich. For inhibition kinetics, four concentrations of 2 (ranging from 0 to $20 \mathrm{nM}$ ) and five concentrations of kynuramine (from 2 to $30 \mu \mathrm{M}$ ) were used. Direct spectrophotometric measurement of 4-hydroxyquinoline absorption at $316 \mathrm{~nm}$ was performed as described. ${ }^{47}$ Inhibition values and kinetic parameters were calculated by means of Prism.

4.2.4. Inhibition of PHF6 Aggregation. The fluorimetric assay, using thioflavin $\mathrm{T}$ as the chromophoric reagent, has already been described. ${ }^{45}$ Briefly, samples of PHF6 (JPT Peptide Technologies $\mathrm{GmbH}$, Berlin, Germany) $(50 \mu \mathrm{M})$, inhibitor $(10 \mu \mathrm{M})$, and ThT $(10$ $\mu \mathrm{M})$ were prepared in triplicate in PBS containing $3.3 \%$ of $1,1,1$ trifluoroethanol and read within $3 \mathrm{~h}$ at $30{ }^{\circ} \mathrm{C}$ with a Tecan Infinite M1000 Pro instrument. The plateau values (as \% of residual activity compared to control) were used for the calculation of residual aggregation or in nonlinear regression by means of Prism to calculate the $\mathrm{IC}_{50}$ values as the mean of two independent experiments.
4.2.5. Inhibition of R3 Aggregation. A stock solution of $1.5 \mathrm{mM}$ R3 (trifluoroacetate salt; Bachem, Bubendorf, Switzerland) was prepared in TFE and left overnight at room temperature. Incubation samples were set in nonbinding, flat-bottomed black microplates (Greiner Bio-One) in triplicate for each concentration and contained peptide $(25 \mu \mathrm{M})$, inhibitor (seven concentrations ranging from 30 to $0.1 \mu \mathrm{M})$, and ThT $(10 \mu \mathrm{M})$ in PBS containing $1.7 \%$ of $1,1,1-$ trifluoroethanol. Fluorescence was read within $4 \mathrm{~h}$ at $37{ }^{\circ} \mathrm{C}$ with a Tecan Infinite M1000 Pro instrument. $\mathrm{IC}_{50}$ values were calculated by means of Prism as the mean of two independent experiments.

4.2.6. Atomic Force Microscopy. Compounds 2, 5, 11, and 12 were dissolved in DMSO at concentrations ranging from $2.0 \mathrm{mg} / \mathrm{mL}$ to $3.3 \mathrm{mg} / \mathrm{mL}$. $\mathrm{A} \beta_{42}$ (Bachem) was dissolved in TFA to obtain a 1 $\mathrm{mg} / \mathrm{mL}$ stock solution. In each experiment, appropriate peptide aliquots were deposited in glass vials and dried under a gentle nitrogen stream. Aggregation was initiated by hydrating the peptide with PBS premixed with the compound under study. The final compound and peptide concentrations were $100 \mu \mathrm{M}$ and $50 \mu \mathrm{M}$, respectively. In the control samples, PBS was premixed with DMSO volumes equivalent to those present in the compound aliquots employed for the experiments. Aggregation was performed at room temperature.

For AFM inspection, sample aliquots of $20 \mu \mathrm{L}$ were deposited on a freshly cleaved mica surface and incubated for $7 \mathrm{~min}$. Samples were then gently rinsed with Milli- $Q$ water and dried overnight under mild vacuum. Tapping mode AFM images were acquired in air using a Dimension 3100 SPM (Bruker, Karlsruhe, Germany) equipped with "G" scanning head (maximum scan size $100 \mu \mathrm{m}$ ) and driven by a Nanoscope IIIa controller (Bruker). Single-beam uncoated silicon cantilevers (type TESPA V2, Bruker) were used. The drive frequency was $300-320 \mathrm{kHz}$, and the scan rate was $0.5 \mathrm{~Hz}$.

4.2.7. Primary Cultures. Cerebellar granule cells were prepared from 8-day-old Sprague Dawley rats as described previously. ${ }^{66}$ Cells were studied from the 6th to the 12th day in vitro. The experimental procedures and care of the animals were performed in compliance with the Directive of the EU Parliament and Council of September $22,2010(2010 / 63 / \mathrm{EU})$ and were approved by the Italian Ministry of Health (COD. 75F11.N.6DX) in accordance with D.M. 116/1992. All efforts were made in order to minimize animal suffering and the number of animals necessary to obtain reliable results.

4.2.8. Cell Survival Assay. Cerebellar granule cells in 48-well plate were treated with $\mathrm{A} \beta_{42}$, aggregated in PBS for $24 \mathrm{~h}$, in the absence and in the presence of each tested compound in the same conditions described in section 4.2.6. The final compound and $\mathrm{A} \beta_{42}$ concentrations after addition to the well plate were $10 \mu \mathrm{M}$ and 5 $\mu \mathrm{M}$, respectively. Cells were maintained in $5 \% \mathrm{CO}_{2}$ at $37^{\circ} \mathrm{C}$. The cell viability was assessed by the MTT assay $48 \mathrm{~h}$ after the treatment. MTT [3-(4,5-dimethyl-2-thiazolyl)-2,5-diphenyl-2H-tetrazolium bromide] (Sigma-Aldrich, Germany) was added to the medium at a concentration of $0.25 \mathrm{mg} / \mathrm{mL}$ (MTT) into each well, and the multiwell plates were incubated for $3 \mathrm{~h}$ at $37^{\circ} \mathrm{C}$. After the removal of the medium, formazan crystals were dissolved in DMSO and the values of optical density (OD) were measured spectrophotometrically at $570 \mathrm{~nm}$ using a BioTek ELx800 (Winooski, VT, USA) microplate reader. The survival rates of viable cells were calculated by comparing the optical absorbance of treated samples with that of the untreated controls. All experiments were repeated at least three times independently, and data are expressed as the mean \pm SEM.

4.2.9. In Vitro Blood-Brain Barrier Permeation Assay (PAMPA$B B B)$. Prediction of the brain permeation of compounds 2, 5, 8, 11, and 12 was evaluated using a parallel artificial membrane permeation assay (PAMPA-BBB), following a well-established procedure. ${ }^{40,50}$ Briefly, a semiautomated pipetting system (BenchSmart 96, Mettler Toledo) and a microplate spectrophotometer (SpectraMax Plus 384 microplate reader, Molecular Devices) were employed for pipetting and UV reading, respectively. All commercial drugs and reagents were purchased from Sigma-Aldrich. The porcine brain lipid (PBL) was acquired from Avanti Polar Lipids, while Millex filter units (PVDF membrane, pore size $0.45 \mu \mathrm{m}$ ) were obtained from Millipore. For the assay, the 96-well acceptor microplate (PTFE, Millipore) was filled 
with $300 \mu \mathrm{L}$ of PBS:ethanol (70:30), whereas the artificial membrane of the donor microplate (PVDF membrane, pore size $0.45 \mu \mathrm{m}$, Millipore) was coated with 4 or $5 \mu \mathrm{L}$ of PBL dissolved in dodecane $(20 \mathrm{mg} / \mathrm{L})$. All compounds were first dissolved in DMSO and then diluted with $\mathrm{PBS} / \mathrm{EtOH}(70: 30, \mathrm{pH}$ 7.4) to reach the final concentration in the range $40-100 \mu \mathrm{M}$ in the donor well, filtered through a Millex filter, and then added to the donor microplate wells $(200 \mu \mathrm{L})$. The donor filter microplate was carefully placed onto the acceptor microplate so as to form a sandwich, which was left undisturbed for $16 \mathrm{~h}$ at $25{ }^{\circ} \mathrm{C}$ into a sealed container with wet paper towels to avoid evaporation. After incubation, the donor microplate was cautiously removed and the concentrations of the tested compounds in the acceptor and donor microplate wells were determined via UV-vis spectroscopy. Every sample was analyzed at five wavelengths in four wells and in three independent runs. Accordingly, the results given in Table 1 are reported as average values \pm standard deviation. $P_{\mathrm{e}}$ was calculated by the following formula: $P_{\mathrm{e}}=\left\{-V_{\mathrm{d}} V_{\mathrm{a}} /\left[\left(V_{\mathrm{d}}+V_{\mathrm{a}}\right) A t\right]\right\} \times \ln \left(1-\right.$ drug $_{\text {acceptor }} /$ $\left.\operatorname{drug}_{\text {equilibrium }}\right)$, where $V_{\mathrm{d}}$ and $V_{\mathrm{a}}$ are the volumes of the donor and acceptor wells, respectively, $A$ is artificial membrane area, $t$ is the permeation time, drug acceptor is the absorbance obtained in the acceptor well, and drug equilibrium is the theoretical equilibrium absorbance. Twenty known commercial drugs of known BBB permeability (Table S1, Figure S1) were used as quality control standards to validate and normalize the analysis set. Donepezil and quercetin were further tested as CNS+ and CNS- positive and negative controls, respectively (Table 1). Upon completion of the PAMPA-BBB assay for each present and standard compound, lipid membrane integrity was verified based on the transport of Lucifer Yellow (Sigma-Aldrich), a fluorescent molecule with very poor membrane permeability which, in the presence of a uniform and integral lipid membrane, should effectively be completely rejected. ${ }^{67}$ The Lucifer Yellow test was performed following Millipore protocol lit. no. PC1545EN00 (https://www.sigmaaldrich.com/technicaldocuments/protocols/biology/membrane-integrity-test-for-lipidpampa-artificial-membranes.html). As the relevant fluorescence readings (SpectraMax Gemini XPS microplate reader, Molecular Devices) were comparable to background readings of buffer only (5\% DMSO in PBS), the membrane integrity after all PAMPA-BBB assays was confirmed.

4.3. Molecular Modeling Studies. All simulations were carried our using Amber $20^{68}$ running on our own CPU/GPU cluster. Molecular graphics and analyses were performed with UCSF Chimera (v1.15), ${ }^{69}$ developed by the Resource for Biocomputing, Visualization, and Informatics at the University of California, San Francisco, with support from NIH Grant P41-GM103311. The starting molecular structure of MAO B in complex with E98 was obtained from the Protein Data Bank (PDB code 6FWC.pdb), ${ }^{70}$ while the $\mathrm{AChE}$ structure in complex with a flavonoid-based inhibitor was taken from our previous work ${ }^{50,51}$ (original PBD code 4EY7). ${ }^{71}$ The entire modeling and simulation procedure is also reported in detail in earlier papers. ${ }^{5,51}$ Briefly, the geometry- and energy-optimized structure of compound 2 was docked into each identified protein binding pocket using Autodock 4.2.6/Autodock Tools $1.4 .6161^{72}$ on a win64 platform. The resulting complexes were further energy minimized to convergence. Each intermolecular complex was then solvated by a cubic box of TIP3P water molecules ${ }^{73}$ and energy minimized using a combination of molecular dynamics (MD) techniques. ${ }^{50,51} 20 \mathrm{~ns}$ molecular dynamics (MD) simulations at $298 \mathrm{~K}$ were then employed for system equilibration, and further, $50 \mathrm{~ns} \mathrm{MD}$ simulations were run for data production. The binding free energies of the $2 / \mathrm{MAO} B$ and 2/AChE complexes were calculated following the MM/PBSA methodology ${ }^{74}$ as previously described. ${ }^{50-56}$ The PRBFED analysis was carried out using the molecular mechanics/generalized Boltzmann surface area (MM/GBSA) approach, ${ }^{75}$ as already detailed, $^{50,51}$ and was based on the same snapshots used in the binding free energy calculation.

\section{ASSOCIATED CONTENT}

\section{Supporting Information}

The Supporting Information is available free of charge at https://pubs.acs.org/doi/10.1021/acschemneuro.0c00624.

Permeability data $\left(P_{\mathrm{e}}, 10^{-6} \mathrm{~cm} / \mathrm{s}\right)$ of 20 commercial drugs used in the PAMPA-BBB assay validation (Table S1) and linear correlation between experimental and reported $P_{\mathrm{e}}$ of the 20 commercial drugs using the PAMPA-BBB assay (Figure S1); Lineweaver-Burk plot of inhibition kinetics of MAO B by 2 (Figure S2); fibril surface density after $24 \mathrm{~h}$ of $\mathrm{A} \beta_{42}$ aggregation in the absence and in the presence of the compounds $(2,5,11$, and 12) (Figure S3); ${ }^{1} \mathrm{H}$ and ${ }^{13} \mathrm{C}$ NMR spectra of the newly synthesized compounds 4, 6, 7, and 10-14 (PDF)

\section{AUTHOR INFORMATION}

\section{Corresponding Author}

Michele Tonelli - Department of Pharmacy, University of Genoa, 16132 Genoa, Italy; (1) orcid.org/0000-0003-15182890; Email: tonelli@difar.unige.it

\section{Authors}

Marta Campora - Department of Pharmacy, University of Genoa, 16132 Genoa, Italy

Claudio Canale - Department of Physics, University of Genoa, 16146 Genoa, Italy

Elena Gatta - Department of Physics, University of Genoa, 16146 Genoa, Italy

Bruno Tasso - Department of Pharmacy, University of Genoa, 16132 Genoa, Italy

Erik Laurini - Molecular Biology and Nanotechnology Laboratory (MolBNL@UniTS), Department of Engineering and Architecture, University of Trieste, 34127 Trieste, Italy; (1) orcid.org/0000-0001-6092-6532

Annalisa Relini - Department of Physics, University of Genoa, 16146 Genoa, Italy; (i) orcid.org/0000-0002-4040-9279

Sabrina Pricl - Molecular Biology and Nanotechnology Laboratory (MolBNL@UniTS), Department of Engineering and Architecture, University of Trieste, 34127 Trieste, Italy; Department of General Biophysics, Faculty of Biology and Environmental Protection, University of Lodz, 90-236 Lodz, Poland

Marco Catto - Department of Pharmacy-Drug Sciences, University of Bari Aldo Moro, 70125 Bari, Italy; (1) orcid.org/0000-0002-8411-304X

Complete contact information is available at:

https://pubs.acs.org/10.1021/acschemneuro.0c00624

\section{Author Contributions}

M.T. conceived the study. M.T. and M.Cam. synthesized the molecules. M.Cam. and B.T. provided their structural characterization. M.Cat. performed inhibition studies against $\mathrm{A} \beta$ and PHF6 aggregation, cholinesterases, and MAO enzymes. E.L. and S.P. performed PAMPA test and docking studies. C.C. and A.R. performed AFM studies. E.G. performed cytotoxicity and neuroprotection assays. M.T., M.Cat., A.R., and S.P. analyzed and discussed the results. M.T., M.Cat., A.R., and S.P. wrote and reviewed the manuscript. All authors have read and agreed to the published version of the manuscript.

\section{Notes}

The authors declare no competing financial interest. 


\section{ACKNOWLEDGMENTS}

M.T., A.R., and C.C. acknowledge the dedicated technical assistance of Dr. Mattia Siri to the AFM study. We thank Prof. Tullio Florio (University of Genoa, Department of Internal Medicine, Section of Pharmacology) for access to the microplate reader.

\section{REFERENCES}

(1) Contestabile, A. (2011) The history of the cholinergic hypothesis. Behav. Brain Res. 221, 334-340.

(2) Masters, C. L., and Selkoe, D. J. (2012) Biochemistry of amyloid $\beta$-protein and amyloid deposits in Alzheimer Disease. Cold Spring Harbor Perspect. Med. 2, a006262.

(3) Jin, M., Shepardson, N., Yang, T., Chen, G., Walsh, D., and Selkoe, D. J. (2011) Soluble amyloid $\beta$-protein dimers isolated from Alzheimer cortex directly induce Tau hyperphosphorylation and neuritic degeneration. Proc. Natl. Acad. Sci. U. S. A. 108, 5819-5824.

(4) Ricciarelli, R., and Fedele, E. (2017) The amyloid cascade hypothesis in Alzheimer's disease: it's time to change our mind. Curr. Neuropharmacol. 15, 926-935.

(5) Oset-Gasque, M. J., and Marco-Contelles, J. (2018) Alzheimer's Disease, the "One-Molecule, One-Target" Paradigm, and the Multitarget Directed Ligand Approach. ACS Chem. Neurosci. 9, 401-403.

(6) Butterfield, D. A. (2018) Perspectives on Oxidative Stress in Alzheimer's Disease and Predictions of Future Research Emphases. J. Alzheimer's Dis. 64, S469-S479.

(7) Li, Y., Jiao, Q., Xu, H., Du, X., Shi, L., Jia, F., and Jiang, H. (2017) Biometal Dyshomeostasis and Toxic Metal Accumulations in the Development of Alzheimer's Disease. Front. Mol. Neurosci. 10, 339.

(8) Heneka, M. T., O’Banion, M. K., Terwel, D., and Kummer, M. P. (2010) Neuroinflammatory processes in Alzheimer's disease. J. Neural Transm. (Vienna) 117, 919-947.

(9) Alam, J., and Sharma, L. (2019) Potential enzymatic targets in Alzheimer's: a comprehensive review. Curr. Drug Targets 20, 316339.

(10) Blaikie, L., Kay, G., and Lin, P. K. T. (2019) Current and emerging therapeutic targets of Alzheimer's disease for the design of multi-target directed ligands. MedChemComm 10, 2052.

(11) Rosini, M., Simoni, E., Caporaso, R., and Minarini, A. (2016) Multitarget strategies in Alzheimer's disease: benefits and challenges on the road to therapeutics. Future Med. Chem. 8, 697-771.

(12) Prati, F., Cavalli, A., and Bolognesi, M. L. (2016) Navigating the chemical space of multitarget-directed ligands: from hybrids to fragments in Alzheimer's disease. Molecules 21, 466.

(13) Mesiti, F., Chavarria, D., Gaspar, A., Alcaro, S., and Borges, F. (2019) The chemistry toolbox of multitarget-directed ligands for Alzheimer's disease. Eur. J. Med. Chem. 181, 111572.

(14) Paul, A., Viswanathan, G. K., Mahapatra, S., Balboni, G., Pacifico, S., Gazit, E., and Segal, D. (2019) Antagonistic activity of naphthoquinone-based hybrids toward amyloids associated with Alzheimer's disease and type-2 diabetes. ACS Chem. Neurosci. 10, $3510-3520$.

(15) Campora, M., Francesconi, V., Schenone, S., Tasso, B., and Tonelli, M. (2021) Journey on Naphthoquinone and Anthraquinone Derivatives: New Insights in Alzheimer's Disease. Pharmaceuticals 14, 33.

(16) Tonelli, M., Catto, M., Tasso, B., Novelli, F., Canu, C., Iusco, G., Pisani, L., Stradis, A. D., Denora, N., Sparatore, A., Boido, V., Carotti, A., and Sparatore, F. (2015) Multitarget therapeutic leads for Alzheimer's disease: quinolizidinyl derivatives of bi- and tricyclic systems as dual inhibitors of cholinesterases and $\beta$-Amyloid $(\mathrm{A} \beta)$ aggregation. ChemMedChem 10, 1040-1053.

(17) Zhang, J. H., Xin, H. L., Xu, Y. M., Shen, Y., He, Y. Q., HsienYeh, Lin, B., Song, H. T., Juan-Liu, Yang, H. Y., Qin, L. P., Zhang, Q. Y., and $\mathrm{Du}, \mathrm{J}$. (2018) Morinda officinalis How. - A comprehensive review of traditional uses, phytochemistry and pharmacology. J. Ethnopharmacol. 213, 230-255.

(18) Augustin, N., Nuthakki, V. K., Abdullaha, M., Hassan, Q. P., Gandhi, S. G., and Bharate, S. B. (2020) Discovery of helminthosporin, an anthraquinone isolated from Rumex abyssinicus Jacq as a dual cholinesterase inhibitor. ACS Omega 5, 1616-1624.

(19) Gazit, E. (2002) A possible role for pi-stacking in the selfassembly of amyloid fibrils. FASEB J. 16, 77-83.

(20) Kirkitadze, M. D., and Kowalska, A. (2005) Molecular mechanisms initiating amyloid beta-fibril formation in Alzheimer's disease. Acta Biochim. Polym. 52, 417-423.

(21) Chierrito, T., Pedersoli-Mantoani, S., Roca, C., Requena, C., Sebastian-Perez, V., Castillo, W. O., Moreira, N., Pérez, C., SakamotoHojo, E. T., Takahashi, C. S., Jiménez-Barbero, J., Cañada, F. J., Campillo, N. E., Martinez, A., and Carvalho, I. (2017) From dual binding site acetylcholinesterase inhibitors to allosteric modulators: a new avenue for disease-modifying drugs in Alzheimer's disease. Eur. J. Med. Chem. 139, 773-791.

(22) Viayna, E., Sabate, R., and Muñoz-Torrero, D. (2013) Dual inhibitors of $\beta$-amyloid aggregation and acetylcholinesterase as multitarget anti-Alzheimer drug candidates. Curr. Top. Med. Chem. 13, $1820-1842$

(23) Lane, R. M., Potkin, S. G., and Enz, A. (2006) Targeting acetylcholinesterase and butyrylcholinesterase in dementia. Int. J. Neuropsychopharmacol. 9, 101-124.

(24) Caraci, F., Pappalardo, G., Basile, L., Giuffrida, A., Copani, A., Tosto, R., Sinopoli, A., Giuffrida, M. L., Pirrone, E., Drago, F., Pignatello, R., and Guccione, S. (2015) Neuroprotective effects of the monoamine oxidase inhibitor tranylcypromine and its amide derivatives against $\mathrm{A} \beta(1-42)$-induced toxicity. Eur. J. Pharmacol. $764,256-263$.

(25) Cai, Z. (2014) Monoamine oxidase inhibitors: promising therapeutic agents for Alzheimer's disease. Mol. Med. Rep. 9, 15331541.

(26) Riederer, P., Danielczyk, W., and Grünblatt, E. (2004) Monoamine oxidase-B inhibition in Alzheimer's disease. NeuroToxicology 25, 271-277.

(27) Weinreb, O., Amit, T., Bar-Am, O., and Youdim, M. B. (2016) Neuroprotective effects of multifaceted hybrid agents targeting MAO, cholinesterase, iron and $\beta$-amyloid in ageing and Alzheimer's disease. Br. J. Pharmacol. 173, 2080-2094.

(28) Mathew, B., Parambi, D., Mathew, G. E., Uddin, M. S., Inasu, S. T., Kim, H., Marathakam, A., Unnikrishnan, M. K., and Carradori, S. (2019) Emerging therapeutic potentials of dual-acting MAO and AChE inhibitors in Alzheimer's and Parkinson's diseases. Arch. Pharm. (Weinheim, Ger.) 352, 1900177.

(29) Ibrahim, M. M., and Gabr, M. T. (2019) Multitarget therapeutic strategies for Alzheimer's disease. Neural Regener. Res. $14,437-440$.

(30) Choi, W. H., Hong, S. S., Lee, S. A., Han, X. H., Lee, K. S., Lee, M. K., Hwang, B. Y., and Ro, J. S. (2005) Monoamine oxidase inhibitory naphthoquinones from the roots of Lithospermum erythrorhizon. Arch. Pharmacal Res. 28, 400-404.

(31) Mostert, S., Petzer, A., and Petzer, J. P. (2016) Evaluation of natural and synthetic 1,4-naphthoquinones as inhibitors of monoamine oxidase. Chem. Biol. Drug Des. 87, 737-746.

(32) Banik, A., Brown, R. E., Bamburg, J., Lahiri, D. K., Khurana, D., Friedland, R. P., Chen, W., Ding, Y., Mudher, A., Padjen, A. L., Mukaetova-Ladinska, E., Ihara, M., Srivastava, S., Padma Srivastava, M. V., Masters, C. L., Kalaria, R. N., and Anand, A. (2015) Translation of pre-clinical studies into successful clinical trials for Alzheimer's disease: what are the roadblocks and how can they be overcome? J. Alzheimer's Dis. 47, 815-843.

(33) Prachayasittikul, V., Pingaew, R., Worachartcheewan, A. Nantasenamat, C., Prachayasittikul, S., Ruchirawat, S., and Prachayasittikul, V. (2014) Synthesis, anticancer activity and QSAR study of 1,4-naphthoquinone derivatives. Eur. J. Med. Chem. 84, 247263. 
(34) Singh, V. K., Verma, S. K., Kadu, R., and Mobin, S. M. (2015) Identification of unusual $\mathrm{C}-\mathrm{Cl} \cdots \pi$ contacts in 2-(alkylamino)-3chloro-1,4-naphthoquinones: effect of $\mathrm{N}$-substituents on crystal packing, fluorescence, redox and anti-microbial properties. RSC Adv. 5, 43669-43686.

(35) Shrestha-Dawadi, P. B., Bittner, S., Fridkin, M., and Rahimipour, S. (1996) On the synthesis of naphthoquinonyl heterocyclic amino acids. Synthesis 1996, 1468-1472.

(36) Rivera-Ávalos, E., de Loera, D., Araujo-Huitrado, J. G., Escalante-García, I. L., Muñoz-Sánchez, M. A., Hernández, H., López, J. A., and López, L. (2019) Synthesis of amino acidnaphthoquinones and in vitro studies on cervical and breast cell lines. Molecules 24, 4285.

(37) Havlícková, L., and Arient, J. (1970) Anthraquinone dyes. Part VI. Nuclear alkylation of 1-aminoanthraquinone leuco-derivative. $J$. Chem. Soc. C, 570-572.

(38) Carta, A., Palomba, M., Boatto, G., Busonera, B., Murreddu, M., and Loddo, R. (2004) Synthesis and antiproliferative activity of 3-aryl2 -[1H(2H)-benzotriazol-1(2)-yl $]$ acrylonitriles variously substituted: Part 4. Farmaco 59, 637-644.

(39) Carpenter, T. S., Kirshner, D. A., Lau, E. Y., Wong, S. E., Nilmeier, J. P., and Lightstone, F. C. (2014) A method to predict blood-brain barrier permeability of drug-like compounds using molecular dynamics simulations. Biophys. J. 107, 630-641.

(40) Di, L., Kerns, E. H., Fan, K., McConnell, O. J., and Carter, G. T. (2003) High throughput artificial membrane permeability assay for blood-brain barrier. Eur. J. Med. Chem. 38, 223-232.

(41) Cellamare, S., Stefanachi, A., Stolfa, D. A., Basile, T., Catto, M., Campagna, F., Sotelo, E., Acquafredda, P., and Carotti, A. (2008) Design, synthesis, and biological evaluation of glycine-based molecular tongs as inhibitors of Abeta1-40 aggregation in vitro. Bioorg. Med. Chem. 16, 4810-4822.

(42) Ellman, G. L., Courtney, D., Andres, V., and Feather-Stone, R. M. (1961) A new and rapid colorimetric determination of acetylcholinesterase activity. Biochem. Pharmacol. 7, 88-95.

(43) Convertino, M., Pellarin, R., Catto, M., Carotti, A., and Caflisch, A. (2009) 9,10-Anthraquinone hinders beta-aggregation: how does a small molecule interfere with Abeta-peptide amyloid fibrillation? Protein Sci. 18, 792-800.

(44) Scherzer-Attali, R., Convertino, M., Pellarin, R., Gazit, E., Segal, D., and Caflisch, A. (2013) Methylations of tryptophan-modified naphthoquinone affect its inhibitory potential toward $\mathrm{A} \beta$ aggregation. J. Phys. Chem. B 117, 1780-1789.

(45) Bolognino, I., Giangregorio, N., Pisani, L., de Candia, M., Purgatorio, R., Tonazzi, A., Altomare, C. D., Cellamare, S., and Catto, M. (2019) A prospective repurposing of dantrolene as multitarget agent for Alzheimer's disease. Molecules 24, 4298.

(46) Jasial, S., Hu, Y., and Bajorath, J. (2017) How frequently are pan-assay interference compounds active? Large-scale analysis of screening data reveals diverse activity profiles, low global hit frequency, and many consistently inactive compounds. J. Med. Chem. 60, 3879-3886.

(47) Pisani, L., Iacobazzi, R. M., Catto, M., Rullo, M., Farina, R., Denora, N., Cellamare, S., and Altomare, C. D. (2019) Investigating alkyl nitrates as nitric oxide releasing precursors of multitarget acetylcholinesterase-monoamine oxidase B inhibitors. Eur. J. Med. Chem. 161, 292-309.

(48) Chuang, H. Y., Patek, D. R., and Hellerman, L. (1974) Mitochondrial monoamine oxidase. Inactivation by pargyline. Adduct formation. J. Biol. Chem. 249, 2381-2384.

(49) Hubálek, F., Binda, C., Li, M., Herzig, Y., Sterling, J., Youdim, M. B., Mattevi, A., and Edmondson, D. E. (2004) Inactivation of purified human recombinant monoamine oxidases $\mathrm{A}$ and $\mathrm{B}$ by rasagiline and its analogues. J. Med. Chem. 47, 1760-1766.

(50) Estrada-Valencia, M., Herrera-Arozamena, C., Pérez, C., Viña, D., Morales-García, J. A., Pérez-Castillo, A., Ramos, E., Romero, A., Laurini, E., Pricl, S., and Rodríguez-Franco, M. I. (2019) New flavonoid - N,N-dibenzyl(N-methyl)amine hybrids: Multi-target- directed agents for Alzheimer's disease endowed with neurogenic properties. J. Enzyme Inhib. Med. Chem. 34, 712-727.

(51) Estrada Valencia, M., Herrera-Arozamena, C., de Andrés, L., Pérez, C., Morales-García, J. A., Pérez-Castillo, A., Ramos, E., Romero, A., Viña, D., Yáñez, M., Laurini, E., Pricl, S., and Rodríguez-Franco, M. I. (2018) Neurogenic and neuroprotective donepezil-flavonoid hybrids with sigma-1 affinity and inhibition of key enzymes in Alzheimer's disease. Eur. J. Med. Chem. 156, 534-553.

(52) Laurini, E., Marson, D., Aulic, S., Fermeglia, M., and Pricl, S. (2020) Computational Alanine Scanning and Structural Analysis of the SARS-CoV-2 Spike Protein/Angiotensin-Converting Enzyme 2 Complex. ACS Nano 14, 11821-11830.

(53) Tonelli, M., Sparatore, A., Basilico, N., Cavicchini, L., Parapini, S., Tasso, B., Laurini, E., Pricl, S., Boido, V., and Sparatore, F. (2020) Quinolizidine-Derived Lucanthone and Amitriptyline Analogues Endowed with Potent Antileishmanial Activity. Pharmaceuticals 13, 339.

(54) Kronenberg, E., Weber, F., Brune, S., Schepmann, D., Almansa, C., Friedland, K., Laurini, E., Pricl, S., and Wünsch, B. (2019) Synthesis and Structure-Affinity Relationships of Spirocyclic Benzopyrans with Exocyclic Amino Moiety. J. Med. Chem. 62, 4204-4217.

(55) Genini, D., Brambilla, L., Laurini, E., Merulla, J., Civenni, G., Pandit, S., D'Antuono, R., Perez, L., Levy, D. E., Pricl, S., Carbone, G. M., and Catapano, C. V. (2017) Mitochondrial dysfunction induced by a $\mathrm{SH} 2$ domain-targeting STAT3 inhibitor leads to metabolic synthetic lethality in cancer cells. Proc. Natl. Acad. Sci. U. S. A. 114, E4924-E4933.

(56) Gibbons, D. L., Pricl, S., Posocco, P., Laurini, E., Fermeglia, M., Sun, H., Talpaz, M., Donato, N., and Quintás-Cardama, A. (2014) Molecular dynamics reveal BCR-ABL1 polymutants as a unique mechanism of resistance to PAN-BCR-ABL1 kinase inhibitor therapy. Proc. Natl. Acad. Sci. U. S. A. 111, 3550-3555.

(57) Wilcken, R., Zimmermann, M. O., Lange, A., Joerger, A. C., and Boeckler, F. M. (2013) Principles and applications of halogen bonding in medicinal chemistry and chemical biology. J. Med. Chem. $56,1363-88$.

(58) Ittner, L. M., and Götz, J. (2011) Amyloid- $\beta$ and tau-a toxic pas de deux in Alzheimer's disease. Nat. Rev. Neurosci. 12, 67-72.

(59) Guo, J. P., Arai, T., Miklossy, J., and McGeer, P. L. (2006) Abeta and tau form soluble complexes that may promote self aggregation of both into the insoluble forms observed in Alzheimer's disease. Proc. Natl. Acad. Sci. U. S. A. 103, 1953-1958.

(60) Blurton-Jones, M., and Laferla, F. M. (2006) Pathways by which Abeta facilitates tau pathology. Curr. Alzheimer Res. 3, 437448.

(61) Dammers, C., Yolcu, D., Kukuk, L., Willbold, D., Pickhardt, M., Mandelkow, E., Horn, A. H., Sticht, H., Malhis, M. N., Will, N., Schuster, J., and Funke, S. A. (2016) Selection and characterization of Tau binding D-enantiomeric peptides with potential for therapy of Alzheimer disease. PLoS One 11, e0167432.

(62) Lee, G., Cowan, N., and Kirschner, M. (1988) The primary structure and heterogeneity of tau protein from mouse brain. Science $239,285-288$.

(63) Adamcik, J., Sánchez-Ferrer, A., Ait-Bouziad, N., Reynolds, N. P., Lashuel, H. A., and Mezzenga, R. (2016) Microtubule-binding R3 fragment from tau self-assembles into giant multistranded amyloid ribbons. Angew. Chem., Int. Ed. 55, 618-622.

(64) Chen, K., Maley, J., and Yu, P. H. (2006) Potential implications of endogenous aldehydes in beta-amyloid misfolding, oligomerization and fibrillogenesis. J. Neurochem. 99, 1413-1424.

(65) Pisani, L., Catto, M., De Palma, A., Farina, R., Cellamare, S., and Altomare, C. D. (2017) Discovery of potent dual binding site acetylcholinesterase inhibitors via homo- and heterodimerization of coumarin-based moieties. ChemMedChem 12, 1349-1358.

(66) Robello, M., Amico, C., and Cupello, A. (1993) Regulation of $\mathrm{GABA}_{\mathrm{A}}$ receptor in cerebellar granule cells in culture: differential involvement of kinase activities. Neuroscience 53, 131-138.

(67) Berben, P., Bauer-Brandl, A., Brandl, M., Faller, B., Flaten, G. E., Jacobsen, A. C., Brouwers, J., and Augustijns, P. (2018) Drug 
permeability profiling using cell-free permeation tools: Overview and applications. Eur. J. Pharm. Sci. 119, 219-233.

(68) Case, D. A., Belfon, K., Ben-Shalom, Y., Brozell, S. R., Cerutti, D. S., Cheatham, T. E., III, Cruzeiro, V. W. D., Darden, T. A., Duke, R. E., Giambasu, G., Gilson, M. K., Gohlke, H., Goetz, A. W., Harris, R., Izadi, S., Izmailov, S. A., Kasavajhala, K., Kovalenko, A., Krasny, R., Kurtzman, T., Lee, T. S., LeGrand, S., Li, P., Lin, C., Liu, J., Luchko, T., Luo, R., Man, V., Merz, K. M., Miao, Y., Mikhailovskii, O., Monard, G., Nguyen, H., Onufriev, A., Pan, F., Pantano, S., Qi, R., Roe, D. R., Roitberg, A., Sagui, C., Schott-Verdugo, S., Shen, J., Simmerling, C. L., Skrynnikov, N. R., Smith, J., Swails, J., Walker, R. C., Wang, J., Wilson, L., Wolf, R. M., Wu, X., Xiong, Y., Xue, Y., York, D. M., and Kollman, P. A. (2020) AMBER 2020, University of California, San Francisco, CA, U.S.

(69) Pettersen, E. F., Goddard, T. D., Huang, C. C., Couch, G. S., Greenblatt, D. M., Meng, E. C., and Ferrin, T. E. (2004) UCSF Chimera-a visualization system for exploratory research and analysis. J. Comput. Chem. 25, 1605-1612.

(70) Reis, J., Manzella, N., Cagide, F., Mialet-Perez, J., Uriarte, E., Parini, A., Borges, F., and Binda, C. (2018) Tight-Binding Inhibition of Human Monoamine Oxidase B by Chromone Analogs: A Kinetic, Crystallographic, and Biological Analysis. J. Med. Chem. 61, 42034212.

(71) Cheung, J., Rudolph, M. J., Burshteyn, F., Cassidy, M. S., Gary, E. N., Love, J., Franklin, M. C., and Height, J. J. (2012) Structures of human acetylcholinesterase in complex with pharmacologically important ligands. J. Med. Chem. 55, 10282-10286.

(72) Morris, G. M., Huey, R., Lindstrom, W., Sanner, M. F., Belew, R. K., Goodsell, D. S., and Olson, A. J. (2009) AutoDock4 and AutoDockTools4: Automated docking with selective receptor flexibility. J. Comput. Chem. 30, 2785-2791.

(73) Jorgensen, W. L., Chandrasekhar, J., Madura, J. D., Impey, R. W., and Klein, M. L. (1983) Comparison of simple potential functions for simulating liquid water. J. Chem. Phys. 79, 926-935.

(74) Massova, I., and Kollman, P. A. (2000) Combined molecular mechanical and continuum solvent approach (MM-PBSA/GBSA) to predict ligand binding. Perspect. Drug Discovery Des. 18, 113-135.

(75) Tsui, V., and Case, D. A. (2000) Theory and applications of the generalized Born solvation model in macromolecular simulations. Biopolymers 56, 275-291. 